\title{
Water quality assessment along Tigris River (Iraq) using water quality index (WQI) and GIS software
}

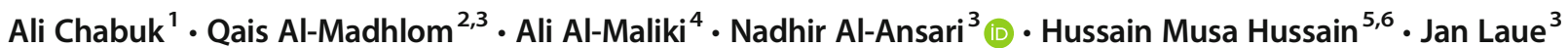

Received: 18 February 2020 / Accepted: 12 June 2020 / Published online: 13 July 2020

(C) The Author(s) 2020

\begin{abstract}
Most of the third world countries having rivers passing through them suffer from the water contaminant problem. This problem is considered so difficult to get the water quality within the standard allowable limits for drinking, as well as for industrial and agricultural purposes. This research aims to assess the water quality of the Tigris River using the water quality index method and GIS software. Twelve parameters ( $\mathrm{Ca}, \mathrm{Mg}, \mathrm{Na}, \mathrm{K}, \mathrm{Cl}, \mathrm{SO}_{4}, \mathrm{HCO}_{3}, \mathrm{TH}, \mathrm{TDS}, \mathrm{BOD}_{5}, \mathrm{NO}_{3}$, and $\mathrm{EC}$ ) were taken from 14 stations along the river. The weighted arithmetic method was applied to compute the water quality index (WQI). The interpolation method (IDW) was applied in ArcGIS 10.5 to produce the prediction maps for 12 parameters at 11 stations along the Tigris River during the wet and dry seasons in 2016. The regression prediction was applied on three stations in the Tigris River between observed values and predicted values, from the prediction maps, in both seasons. The results showed that the regression prediction for all parameters was given the acceptable values of the determination coefficient $\left(R^{2}\right)$. Furthermore, the state of water quality for the Tigris River was degraded downstream of the Tigris River, especially at the station (8) in Aziziyah in the wet and dry seasons and increase degradation clearly at Qurnah (Basrah province) in the south of Iraq. This paper considers the whole length of the Tigris River for the study. This is important to give comprehensive knowledge about the contamination reality of the river. Such that it becomes easier to understand the problem of contamination, analyze it, and then find the suitable treatments and solutions.
\end{abstract}

Keywords Water quality index $\cdot$ Weighted arithmetic method $\cdot$ IDW method $\cdot$ Prediction maps $\cdot$ GIS

\section{Introduction}

Shortage of water resources in the Middle East Region (Frenken 2009; Al-Ansari et al. 2018a; Al-Ansari 2016, 2019a, b) represents crucial factors that control the stability of the region and its progress (Al-Ansari et al. 2018a, b). Prospects indicate that the situation will be gloomier and more complicated (Al-Ansari et al. 2018c; Voss et al. 2013).

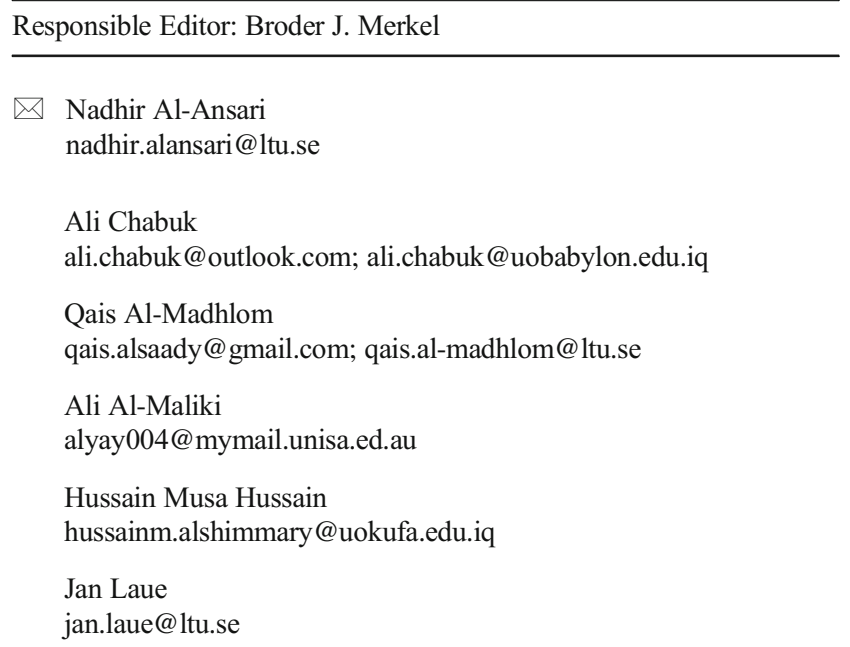

1 Department of Environment Engineering, College of Engineering, University of Babylon, Babylon 51001, Iraq

2 College of Engineering, Al-Musaib, University of Babylon, Babylon 51001, Iraq

3 Department of Civil Environmental and Natural Resources Engineering, Lulea University of Technology, SE-971 87 Lulea, Sweden

4 Ministry of Science and Technology, Baghdad 10001, Iraq

5 Remote Sensing Center, University of Kufa, Kufa 54003, Iraq

6 Department of Geology, Faculty of Science, University of Kufa, Kufa 54003, Iraq 
In Iraq, there are external and internal factors affecting the water quality of water within the rives; they are controlled and uncontrolled factors (Al-Ansari 2013). The uncontrolled factors are climate change and its consequences, such as reduction of precipitation and temperature increasing (Abahussain et al. 2002; Amin et al. 2016; Al-Ansari 2016; Al-Ansari et al. 2018a, b, c; Kibaroglu 2019). The total water resources within the Arabian Peninsula decreased between 0 and $250 \mathrm{~mm}$ during the period 2002 and 2015 (Frenken 2009).

The controlled factors have a significantly negative influence on water resources, but their effects involve more specific regions (Al-Ansari et al. 2018c; Adamo et al. 2018). The controlled factors are mainly represented by building dams and irrigation projects within the upper parts of the catchment (Abahussain et al. 2002; Issa et al. 2014; Al-Ansari et al. 2018b; Kibaroglu 2019). Dam building within the upper parts of the Tigris and Euphrates catchments (Turkey, Syria, and Iran) has a significant effect on surface water in Iraq because about $80 \%$ of the water supply to Euphrates and Tigris Rivers come from Turkey (Adamo et al. 2018).

The policy of dam building on Euphrates and Tigris Rivers represents a historical challenge (Solomon 2010). The Southeastern Anatolian Project (Turkey's Greater Anatolia Project (GAP)) raised this challenge and the tension between Turkey, Syria, and Iraq when Turkey decided unilaterally to construct over 22 dams on both the Tigris and Euphrates Rivers (Bayazit and Avci 1997; Voss et al. 2013). Fourteen of these dams are on the Euphrates River, and the remainder dams are on the Tigris River (Al-Ansari et al. 2018c). The planning of GAP is started in the 1970s (Bilgen 2018). The project includes constructing 19 hydropower plans 52 to produce a total installed hydropower capacity of $7476 \mathrm{MW}$ with annual energy production of 27 billion kilowatt-hours (Ministry of Industry and Technology 2019). The designed total of irrigated land within Turkey is 1.8 million ha (Bilgen 2018). The first dam started in operation in 1987. Till this moment (27th of October 2019), 12 dams from this project were completed and are in operation. The last completed dam (27th of October 2019) is Ilisu Dam, which entered the service in 2018. There is another dam (Silvan Dam) that is expected to be completed in a short period (Daggupati et al. 2017). One of the most important consequences of the dams on the Euphrates and Tigris Rivers is decreasing, significantly, the flow of the two rivers and deterioration of the water quality within Iraq (Al-Ansari et al. 2018b).

There is another challenge that complicates the water problem in Iraq, which is the deterioration of the groundwater (Jassim and Goff 2006; Al-Madhlom et al. 2019). The groundwater quality in the Mesopotamia region (middle and south of Iraq), where population density is high, is very poor. According to the World Bank (2006), Frenken (2009), and Beaumont et al. (2016), most of the people of Iraq settle within the Mesopotamia region where the agriculture land is available "hydraulic civilization." Besides, the storage of groundwater is also affected by climate change and dam constructing. The groundwater storage lost $17.3 \pm 2.1 \mathrm{~mm} / \mathrm{year}$ during the period from January 2003 to December 2009 . This value is equivalent to $91.3 \pm 10.9 \mathrm{~km}^{3}$ in volume (Voss et al. 2013).

Generally, surface water quality is considered as a critical issue in recent times, due to the expected reduction in the quantity of freshwater that will be available in the future. Water quality can be assessed according to its chemical, physical, and biological features, such that measuring these characteristics is considered to determine (Al-Ansari et al. 2018c).

One of the approaches that can be used to sustain the surface water in Iraq is monitoring the sources of the contaminants and trying to prevent/decrease their effects. The most formal used method is evaluating the concentration of the contaminant along the watercourse of the river, determining the contaminants' sources, analyzing the results, explaining the reasons behind the contamination, and finding methods that can be used to decrease their effect, or in the worst cases, finding suitable methods that can be used to invest the contaminated water. This process aims to remove or decrease the contaminants as much as possible to produce good quality water that can satisfy the standards of drinking, irrigation, and industrial uses.

Geographical information system (GIS) with remote sensing and mapping has necessary roles to play in all geographic and spatial aspects of the development and management of water resource. Such techniques provide powerful analytical and visualization tools for describing, analyzing, and modeling the natural system process and functions. Moreover, experimentation with the satellite image analysis and cross-checking with the field data can give an alternative and accurate parameter detection technique. Several authors have demonstrated the advantage of combining satellite image analysis with field data to assess the accuracy of water quality detection (Carré and Girard 2002; Bishop et al. 2001; Bouaziz et al. 2011; Morshed et al. 2016). A significant amount of research has been conducted to develop interpolate methods and spatial analysis modeling. These methods range from semi-empirical techniques to analytical methods for estimating and producing quantitative or qualitative water maps (Dekker 1993). Although mathematical modeling of river water quality needs more hydraulics and hydrodynamics data, and it requires wide validation (Madhloom and Alansari 2018), the water quality index (WQI) in conjunction with (GIS) can be used to overcome most of the mentioned problems above and can specify the status of the water (i.e., excellent, good, bad, etc.). The GIS has spatial analysis tools to deal with a special huge data, and other mathematical models can be integrated with this program to get on valuable outputs related to many 
scientific and environmental fields (Madhloom and Alansari 2018).

Many studies applied the GIS technique to find solutions to water resources, for example, Srivastava et al. (2011) provided the means to summarize the overall conditions of water quality in a manner that can be connected to decision-makers about the WQI by studying 63 samples about water quality index in Mahi River, India, utilizing the GIS. Another researcher studied physicochemical water samples for evaluating the water quality of the Tigris River (Iraq); they analyzed 96 water samples by using GIS conjunct with WQI (Abbas 2013). Moreover, GIS combined with the analytic hierarchy process (AHP) method is used to assess the synthetically ecoenvironmental quality of Hunan Province, which can help administrators to resolve problems related to ecoenvironmental (Ying et al. 2007). The spatial interpolation techniques such as inverse distance weighted (IDW) has irreplaceable advantages for the assessment of data in rivers because of its high level of accuracy in water quality modeling, and it is widely used especially by earth scientists (Madhloom and Alansari 2018).

Hussain et al. (Hussain and Abed 2019) applied the software of the groundwater modeling system (GMS) together with the GIS software to build the model with threedimensional as well as to determine the groundwater usage by taking the data from 35 wells in the aquifer of Alluvial fan of Mandali, Diyala, Iraq. They selected three scenarios to determine the hydraulic conductivity, coefficient of storage, and specific yield for the wells distributed in the study area depending on minimum drawdown. These scenarios consist of three daily operation times 6,12 , and $18 \mathrm{~h}$. The results using GMS software showed that the maximum drawdowns were at $7 \mathrm{~m}, 11.5 \mathrm{~m}$, and $20 \mathrm{~m}$ for the daily operation time of 6,12 , and $18 \mathrm{~h}$ respectively. Zhang (2019) made a comprehensive study about the analysis of research, publication, countries, citation, and directions that interested by using the (WQI) for river, basin, and groundwater for the previous studies in different countries for the period from 1997 to 2017. Zhang found the subjects about water pollution problems, groundwater, and drinking water pollution, and the management of the river basin has the highest proportion of attention. He found that the top subjects about the researches using the WQI method were (246) in Environmental Sciences and Ecology, (236) in Environmental Sciences, (134) in Water Resources, and other subjects such as Marine and Freshwater Biology, Engineering, Multidisciplinary and Geology, and Geosciences. The water quality index method is considered the most common to assess the water quality in the developing countries to sustain the quality of water because it is played important role in the sustainable development of social-economic in these countries. Mohammed and Abdulrazzaq (2018) used the (WQI) method to evaluate the water quality for drinking along the Euphrates River inside the
Iraqi borders for the years (2013-2014). They used 8 parameters and measured from 11 stations distributed along the river. The results showed that the water quality of the Euphrates River was classified from good to poor. In the first station when it enters the borders of Iraq, the water quality was classified as good water quality. Then the water quality of the river begins to drop gradually until the water quality becomes poor at the station (8) in Al-Koufa, Al-Najaf province, which continues to the last at the station in Al-Samawah, Al-Muthanna province. This is due to that the river water receives the amount of pollution from different sources such as domestic sewage and different industrial effluents. Khudair et al. (2018) used WQI method to evaluate the quality of groundwater for drinking purposes in Baghdad city. Where water samples were drawn from 114 wells distributed within the Baghdad city. These samples were analyzed for $\mathrm{pH}$, chloride $(\mathrm{Cl})$, sulfate (SO4), and total dissolved solids (TDS). They concluded that the WQI divided into five categories are excellent, good, poor, very poor, and unfit, with proportions of $14.9 \%, 39.5 \%$, $22.8 \%, 6.1 \%$, and $16.7 \%$, respectively.

Based on the mentioned facts, it becomes very important maintaining or sustaining the water resources in the country, particularly the surface water since it is a vital resource of the water for the country. For a more specific scale, the Tigris River should gain more interest, since its irrigation potential is about 7.245 million ha (about $63 \%$ ) from the total cultivated lands in Iraq (11.5 million ha) (Al-Ansari 2013; The World Bank 2006). Some previous studies considered some of the contaminations either in Tigris River alone or in both Tigris and Euphrates (Mutlak et al. 1980; Numaan 2011; World Bank 2006; Abbas 2013; Rahi and Halihan 2018). Nevertheless, these studies did not cover all the contaminants, or they covered a specific reach on Tigris River and did not cover the whole river within Iraqi regions.

One of the approaches that can be used to sustain the surface water in Iraq is monitoring the sources of the contaminants and trying to prevent/decrease their effects. The most formal used method is evaluating the concentration of the contaminant along the watercourse of the river, determining the contaminants' sources, analyzing the results, explaining the reasons behind the contamination, and finding methods that can be used to decrease their effect, or in the worst cases, finding suitable methods that can be used to invest the contaminated water. This process aims to remove or decrease the contaminants as much as possible to produce good quality water that can satisfy the standards of drinking, irrigation, and industrial uses.

This paper considers $1468 \mathrm{~km}$ from the Tigris river, which is the whole length of the river within the boundary of Iraq, for studying. Eleven stations are used to measure 12 parameters in 2 cases: wet and dry seasons. Since this study demonstrates the values of the 12 parameters along the river, it becomes easier to have a comprehensive background about the 
contamination reality, analyze it, and then find the suitable treatment and solutions. Furthermore, this paper presents a brief updated study about geography, population, climate, topography, argo-ecological system, and the aquatic state of Iraq, so it becomes easier to have a background about the macro study area (Iraq).

The objectives of this paper are finding the concentration of 12 parameters/contaminants, which are essential to determine the water quality along the Tigris River, and mapping the result by using ArcMap/GIS Software 10.5 to produce easily read maps.

The rest of the paper is structured as follows: "Study area and Tigris River hydrology" section describes the study area and the Tigris River. It consists of two subsections. The first one describes the study area; furthermore, it is divided into six subsections: geography, population, climate, topography, agro-ecological systems, and aquatic state. The second subsection describes the Tigris river and its hydrology. "Methodology" section describes the used methodology in this paper, which is subsequently divided into three subsections which describe the considered parameters and stations, the used GIS mapping technique that is used to depict the considered parameters, and basic equations that are used in water quality classification. "Results and discussion" section presents the results and discussion. The results include three subsections; they concern concentration of the parameters, the resultant GIS maps, and the classification of the WQI method at the considered stations. Finally, this paper ends with conclusions.

\section{Study area and Tigris River hydrology}

\section{Study area}

\section{Geography}

Iraq is one of the Middle East countries. It is approximately located on latitude $33^{\circ} 00^{\prime} \mathrm{N}$ (between $29^{\circ} 02^{\prime} \mathrm{N}$ and $37^{\circ} 23^{\prime}$ $\mathrm{N}$ ) and longitude $44^{\circ} 00^{\prime} \mathrm{E}$ (between $38^{\circ} 47^{\prime} \mathrm{E}$ and $48^{\circ} 35^{\prime} \mathrm{E}$ ) (Fig. 1). Its total area is $438,317 \mathrm{~km}^{2}$. The land area is about $437,367 \mathrm{~km}^{2}$; it is about $99.78 \%$ of the total area of the country. The water area is about $950 \mathrm{~km}^{2}$; it is about $0.22 \%$ of the total area. The country is bounded from the east by Iran (1599 km border length), from the North by Turkey (367 km border length), from the west by Syria (599 km border length) and Jordan (179 km border length), and from the south-west and west by Saudi Arabia (811 km border length) and Kuwait (254 km border length). The total length of the borders is $3809 \mathrm{~km}$. Iraq has a strategic location, due to its coastline at the head of the Arab Gulf of length $58 \mathrm{~km}$ (Central Intelligence Agency 2019).

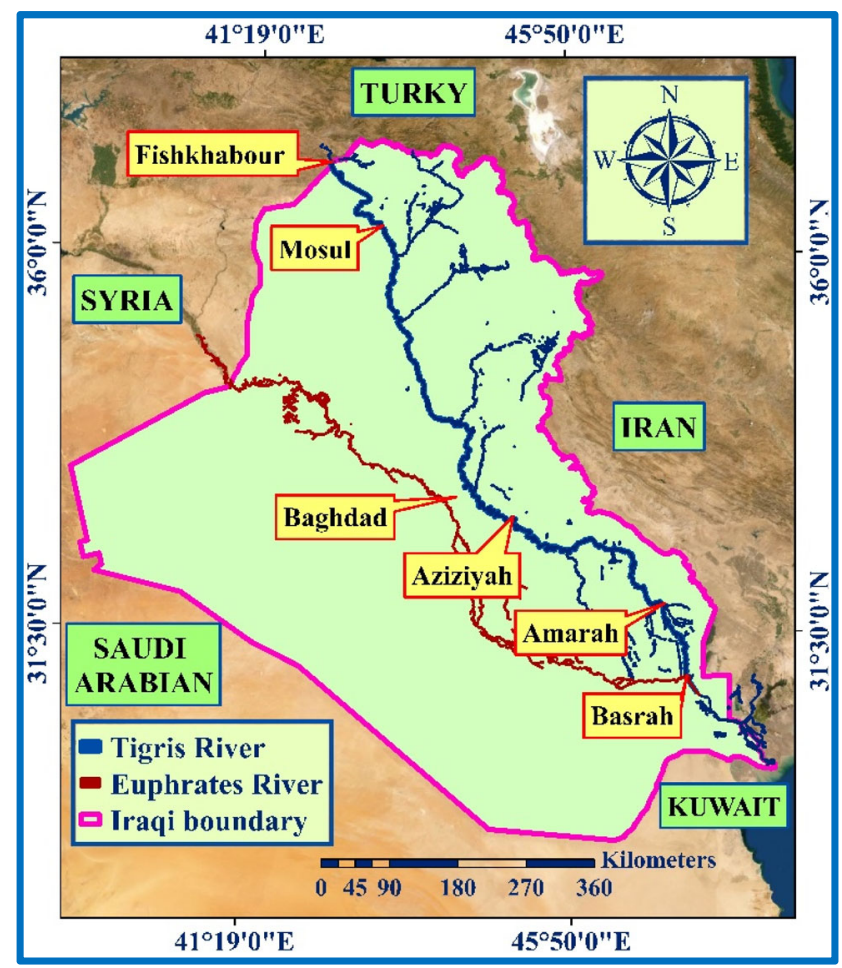

Fig. 1 Map of Tigris River across Iraq

\section{Population}

The country's population is about 40,194,216 (2018), with an estimated growth rate of $2.5 \%$ in 2018. Most of the population settles in the north, center, and eastern parts of the country on both sides of the Tigris and Euphrates Rivers. Great parts of the western and southern areas are either lightly populated or uninhabited, due to a hard environment and lack of welfare facilities because they are desert areas (Central Intelligence Agency 2019).

\section{Climate}

The predominant climate in the middle and southern parts of Iraq is continental, subtropical, arid, and semi-arid. It changes to the Mediterranean in the north and north-eastern mountainous regions of Iraq (Al-Ansari 2013; Al-Ansari et al. 2018c; Central Intelligence Agency 2019). The season of the rainfall is commonly limited to 3 months from December to February, except in the north and northeast of the country, where the rainy season extends to 6 months from November to April. The average annual rainfall is about $216 \mathrm{~mm}$. The average annual rainfall is not equally distributed around the country. It reaches its peak to about $1200 \mathrm{~mm}$ in the northeast of Iraq and decreases about $10 \mathrm{~cm}(>60 \%)$ to the South of the country and Iraqi west desert. Winters are mild to cool, with $16^{\circ} \mathrm{C}$ as day temperature drops to about $2{ }^{\circ} \mathrm{C}$ at night with a possibility of frosting. Summers are dry and hot to extremely hot, with a 
shade temperature commonly over $43{ }^{\circ} \mathrm{C}$ during July and August; at night it drops to $26{ }^{\circ} \mathrm{C}$ (The World Bank 2006; Frenken 2009; CIA 2019). These values are based on records from 1888, until now (National Oceanic and Atmospheric Administration 2019). But during the last years, the temperature changes dramatically due to climate change and global warming. During the last years, the temperature was higher than the recorded by about $5{ }^{\circ} \mathrm{C}$ and in some cases $9{ }^{\circ} \mathrm{C}$ (anomaly). Through the country, the temperature is not even, and it changes spatially. In general, it increases along the direction from the north and north-east to south and southwest. In winter, the temperature increases from $9{ }^{\circ} \mathrm{C}$ (day) and below $0{ }^{\circ} \mathrm{C}$ (night) in the north (Sulaymaniyah city, 2018 ) to about $18{ }^{\circ} \mathrm{C}$ (day) and $6{ }^{\circ} \mathrm{C}$ (night) in the south (Basra city). In the summer, the temperature increases from $42{ }^{\circ} \mathrm{C}$ (day) and $26^{\circ} \mathrm{C}$ (night) in the north to reach $50{ }^{\circ} \mathrm{C}$ (day) and $35^{\circ} \mathrm{C}$ (night) in the south (AccuWeather 2019). The annual evaporation changes proportionally with the temperature (Al-Ansari 2013). It drops from less than $1 \mathrm{~m} \mathrm{n}$ the north to more than $3.5 \mathrm{~m}$ in the south (Al-Jiburi and Al-Basrawi 2015).

\section{Topography}

Topographically, Iraq region can be divided into seven subregions; they are Thrust zone; High folded zone (mountains of sedimentary rock); low folded zone (hills of sedimentary rocks); Al-Jazira zone (plains of sedimentary rocks); Mesopotamia zone (vast flat plain of fluvial sediment); Western Desert zone (flat region of sedimentary rocks with rare gypsum); and Southern desert zone (an extension to the Arabian Peninsula, mainly sedimentary rocks) (Al-Jiburi and Al-Basrawi 2015; Al-Madhlom et al. 2019).

\section{Agro-ecological systems}

Based on the agricultural conditions, Iraq can be divided into four agro-ecological zones (Bishay 2003; Al-Zamili and AlLami 2018; Alwan et al. 2019):

1. Arid and semi-arid zones with a Mediterranean climate (De Pauw et al. 2015; Al-Zamili and Al-Lami 2018; Alwan et al. 2019) for aridity classes. This zone is located in the northern parts of Iraq, i.e., includes Thrust zone and High folded zone. It has long growing seasons of about 9 months. The annual rainfall rates from 1000 to $400 \mathrm{~mm}$. The summer is predominantly mild $\left(20-30^{\circ} \mathrm{C}\right)$ to warm $\left(>30^{\circ} \mathrm{C}\right)$. The major crops in this region are wheat, barley, rice, and chickpea. The main sources of irrigation are spring, steam, and bores (Bishay 2003).

2. Steppes zone with winter rainfall of $200-400 \mathrm{~mm}$ annually (Bishay 2003). This zone is located between the Mediterranean zone and the desert zone. This zone covers the Low folded zone and apart from the Al-Jazira zone
(Al-Jiburi and Al-Basrawi 2015; De Pauw et al. 2015; Alwan et al. 2019). This region has extremely hot summers and cold winters. The main crop is feed barley (Bishay 2003).

3. The desert zone which has extreme summer temperatures and less than $200 \mathrm{~mm}$ of rainfall annually. This region covers the Western and the Southern deserts and a part of the Al-Jazira zone (Al-Jiburi and Al-Basrawi 2015; De Pauw et al. 2015; Al-Zamili and Al-Lami 2018). There are just a few crops that can be irrigated from spots (Bishay 2003).

4. The irrigated area is located between and on the riverine of the Tigris and Euphrates Rivers from the north of Baghdad to Basra in the south. This area has serious problems in drainage and salinity. Agricultural products are mainly represented by vegetables, sunflower, and rice (Bishay 2003).

Based on the agro-ecological systems and agricultural land use, agricultural water demand is determined (FAO 2019a). According to agriculture and type of the plants, the land can be divided into the following classes (FAO 2019b):

- Land area: It is the total area of the country excluding the inland water bodies. For Iraq, it is about 43.4 million ha (FAO 2019b).

- Area suitable for agriculture: For Iraq, it is about 20-25\% of the total area. It is estimated at $22 \%$ (2016 estimation) from the land area (9.5 million ha) (FAO 2019c).

- Cultivated area: It is the area of land, which is actually under agriculture. It includes arable land, permanent crops, and permanent pasture. Considering Iraq, it is estimated about 5300-5200 million ha in 2016, which is about $12 \%$ total area (FAO 2019d). Cultivated land includes both arable land and permanent crops.

- Arable land: It includes land under temporary crops, temporary pasture, kitchen gardens, and fallow land for less than 5 years. Iraq is about $16 \%$ of the total area of Iraq (7 million ha) (FAO 2018).

- Permanent crops: It includes land under cultivation for a long period like fruit trees and coca. Regarding Iraq, it is about $0.78 \%$ of the total area ( 0.34 million ha) (Library of Congress 2006).

- Permanent pasture: It includes land that is used for herbaceous forage crops for 5 years or more; it can be cultivated of wild growing. It is about $9.2 \%$ of the land area of Iraq (4 million ha) (Central Intelligence Agency 2019).

According to FAO (2018), about 7 million ha can be classified as cultivated land. The cropped arable land (used to produce grains, e.g., wheat, barley, and rice) is 5.9 million ha. The irrigated arable cropped land represents $64-66 \%$ of the arable land, i.e., (3.392-3.525) million ha (Frenken 2009; 
FAO 2018; FAO 2019e). Most of the irrigated crops are produced by Mesopotamia Zone, Agro-ecological no. 4, see Agro-ecological systems (The World Bank 2006). The irrigated land can be either surface irrigated or groundwater irrigated. The surface irrigated land is about $94 \%$ of the total irrigated land (FAO 2019e). Most of the irrigated land is located in the Mesopotamia zone, while the north cultivated parts of Iraq depend mainly on rainfall to produce wheat and barley (FAO 2018).

About $63 \%$ of Mesopotamia zone can be potentially irrigated by the Tigris River, 35\% by Euphrates River, and 2\% through Shat Al-Arab (FAO 2008; Al-Ansari 2013).

Classifying the water withdrawals by type of sector, it is obtained that the agriculture sector is the main consumer with ( $90 \%$ from the total withdrawals) of the water in Iraq (Table 1) (The World Bank 2006; FAO 2019f).

\section{Aquatic state}

It is worthy to mention that one of the challenges that the researcher face in the aquatic situation is the fluctuation in the surface resources and the precipitation which affects the statistics in this field (The World Bank 2006; FAO 2008; Frenken 2009). The major part of the water demand in Iraq is covered by Euphrates and Tigris Rivers. The two rivers originate from the south-eastern mountains of Turkey. They enter Iraq along its north-western border with Turkey and Syria. Euphrates and Tigris flow about $1000 \mathrm{~km}$ and $1300 \mathrm{~km}$ within the Iraqi land before they confluence to generate Shatt Al-Arab in the north of Basra. Shatt al-Arab is a tidal channel. It flows for about $190 \mathrm{~km}$ before it joins the Arab Gulf (The World Bank 2006; Frenken 2009).

For the Tigris River, the watershed is about $371,562 \mathrm{~km}^{2}$, and it is as follows: $47 \%$ Iran, $38 \%$ Iraq, $14 \%$ Turkey, and $0.3 \%$ Syria (The World Bank 2006). The annual mean water resources for Iraq since 1932 are shown in Table 2 (The World Bank 2006; FAO 2019g).

The annual amount of the groundwater that can be exploited is environmentally restricted to safe yield. The safe yield can be defined as the amount of the groundwater that can be extracted from the aquifer without introducing negative effects on the environment and the aquifer (Fetter 2018).
The safe yields of the aquifers system in Iraq are stated in Jassim and Goff (2006) and Al-Madhlom et al. (2019). The total annual safe yield for the country is $1.2 \mathrm{BCM}$ (FAO 2019g).

About $70 \%$ of Iraq's water supply originates from the neighboring countries. According to the estimation of the Iraqi Ministry of water resources, during the last 20 years, the levels of Tigris and Euphrates Rivers have fallen by up to $40 \%$ (International Energy Agency 2019). Decreasing the water levels and the flow of the rivers is one of the predominant factors that affect water quality. Besides this factor, many other problems are affecting the water quality such as seawater encroaching upstream; increasing the salinity of the freshwater, especially in the south part of the Mesopotamia zone; and discharging the industrial, sewage, and drainage agricultural water. All these problems increase the deterioration of the water quality beyond the World Health Organization (WHO) standards for drinking water (International Energy Agency 2019).

Building dams at the upstream Euphrates and Tigris Rivers catchments had decreased the annual flow through these rivers dramatically. The evaporation is another important challenger that should be considered in Iraq. The average annual evaporation from open water bodies in the country is about $1410 \mathrm{~mm}$. It is higher than its values in both Iran and Turkey which is $1050 \mathrm{~mm}$ and $720 \mathrm{~mm}$ respectively. This high value of evaporation is due to the latitude of the country (Frenken 2009).

\section{Hydrology of Tigris River}

Tigris River is the second-longest river in southwest Asia after the Euphrates River. It originates from the southern slope of Toros Mountains, particularly Hazar Lake (elevation 1150 a.m.s.l.), which is located in the southwest of Turkey. The headwater of the Tigris River starts from a lake called Jazar Golu about $30 \mathrm{~km}$ north the catchment of Euphrates (Al-Ansari 2013; Issa et al. 2014; Rahi and Halihan 2018). The total length is approximately $1900 \mathrm{~km}$ (Issa et al. 2014), distributed as follows: $400 \mathrm{~km}$ within Turkey, $32 \mathrm{~km}$ Form apart from the Syrian-Turkey borders, and the remainder is within Iraq
Table 1 Annual consumptions of deferent sectors (The World Bank 2006; FAO 2019f)

\begin{tabular}{|c|c|c|c|c|c|c|}
\hline \multirow[t]{2}{*}{ Sector } & \multicolumn{2}{|c|}{ Period (1998-2002) } & \multicolumn{2}{|c|}{ Period (2003-2004) estimated } & \multicolumn{2}{|c|}{ Period (2013-2017) } \\
\hline & $\mathrm{BCM}$ & $\%$ & $\mathrm{BCM}$ & $\%$ & $\mathrm{BCM}$ & $\%$ \\
\hline Agriculture & 39.4 & 92 & 46 & 90 & 35.27 & 91.5 \\
\hline Domestic & 1.4 & 3 & 2.1 & 4 & 1.23 & 3.2 \\
\hline Industrial & 2 & 5 & 3.6 & 6 & 2.05 & 5.3 \\
\hline Total withdrawals & 42.8 & 100 & 51.7 & 100 & 38.55 & 100 \\
\hline
\end{tabular}


Table 2 Annual mean water resources for Iraq (The World Bank 2006; FAO 2008, 2019g)

\begin{tabular}{|c|c|c|c|c|}
\hline Description & Euphrates & Tigris & Groundwater & Total \\
\hline Transboundary annual flow (1932-1970) BCM & 30 & 48 & - & 78 \\
\hline Transboundary annual flow (1971-2003) BCM & 19 & 48 & 0.08 & 67 \\
\hline Turkey annual contribution (1971-2003) BCM (as \% from total flow) & $17.86(94 \%)$ & $27(40 \%)$ & $0(0 \%)$ & 44.86 \\
\hline Mean external annual flow (1970-2003) BCM (as \% from total flow) & $19(100 \%)$ & $32(48 \%)^{\mathrm{a}}$ & $0.08(6.25 \%)$ & $51(59.2 \%)$ \\
\hline Mean internal annual contribution (1970-2003) BCM (as \% from the total flow) & $0(0 \%)$ & $34(52 \%)^{\mathrm{b}}$ & $1.2(93.37 \%)$ & $35.2(40.8 \%)$ \\
\hline Transboundary annual flow (2013-2017) BCM & $15.75^{\mathrm{c}}$ & $31.33^{\mathrm{d}}$ & $0.08^{\mathrm{e}}$ & $47.16^{\mathrm{f}}$ \\
\hline
\end{tabular}

${ }^{\text {a }}$ Including $8 \%$ of the total contributions come from Iran

${ }^{\mathrm{b}}$ All the internal tributaries on the left side bank of the river (FAO 2008)

${ }^{\mathrm{c}}$ The unilateral agreement of Turkey saves $30 \mathrm{BCM}$ as an annual flow for the Euphrates. Subsequently, this value split between Iraq/Syria as $58 \% / 42 \%$ producing 17.4 BCM as a quota of Iraq. Then 17.4 BCM is decreased to $15.75 \mathrm{BCM}$. Finally, Iraq receives just $9 \mathrm{BCM}$ in reality (FAO 2019g)

${ }^{\mathrm{d}}$ It is split as follows: 10 BCM from the Islamic Republic of Iran and 21.33 BCM from Turkey (FAO 2019g)

${ }^{\mathrm{e}}$ The total annual groundwater flow, internal (1.2) and external, is $1.28 \mathrm{BCM}$ (FAO 2019g)

${ }^{\mathrm{f}}$ The actual total flow (surface water + groundwater) is $41.41 \mathrm{BCM}(\mathrm{FAO} 2019 \mathrm{~g}$ )

(Issa et al. 2014). The river enters Iraq at Fishkhabour village at the Iraq-Turkey-Syria triangle border in the northwest of Iraq. The river flows about $1430 \mathrm{~km}$ in the Iraqi before its confluence with the Euphrates River just north Basra city to form Shatt AL-Arab River, which flows south $190 \mathrm{~km}$ before joining the Gulf (The World Bank 2006; Issa et al. 2014).

The catchment of the Tigris River is about $471,606 \mathrm{~km}^{2}$ of which $12 \%$ in Turkey, $0.2 \%$ in Syria, $54 \%$ in Iraq, and $34 \%$ in Iran (FAO 2009; Al-Ansari 2013; Rahi and Halihan 2018). Turkey delivers $51 \%$ of the annual water flow in the Tigris, while the remainder is provided by Iraq and Iran, as shown in Table 3 (FAO 2009). Tigris River is fed by tributaries. The tributaries in Turkey are Butman Su, Karzan, Razuk, and Khabur. The Iran tributaries are Zab (Greater and lesser) and Diyala and Udhamm rivers. The catchment of one tributary (Adhaim) lies within Iraq (Al-Ansari 2013; Issa et al. 2014). The discharge of the river increases from less than $64 \mathrm{~m}^{3} / \mathrm{s}$ to about $413 \mathrm{~km}^{3} / \mathrm{s}$ after merging with Razuk tributary (Al-Ansari 2013). More details about the tributaries and Dams on the Tigris River within Iraq are explained in Tables 3 and 4.

The salinity in Tigris River changes from $280 \mathrm{ppm}$ at the Turkey-Iraq border in the northwest of Iraq to $1800 \mathrm{ppm}$ downstream Basra in the south of Iraq (FAO 2018).

\section{Methodology}

The methodology of this article consists of three approaches; they are field measurements, GIS mapping, and calculations and equations. Below is the description of each one. The description of the schematic diagram of the methodology can be seen in Fig. 2.

\section{Water quality assessment (field measurement)}

Along the Tigris River, 11 locations (stations) were selected to measure 12 parameters in the wet seasons and dry seasons in 2016 from the records of the National Center of Water Resources Management (NCWRM) (2017) and Consulting Engineering Bureau (CEB) (2017). Three locations were used for predicting after implementing the interpolation between the 11 stations using the IDW method in ArcGIS (10.5). For wet seasons, the average of 6 months was adopted which were (January, February, March, October, November, and December), while the average values of other 6 months for the dry seasons were (April, May, June, July, August, and September). The stations of observed values were (Fishkhabour, Al-Mosul Dam, Mosul, Tikrit, Samarra, Muthanna Bridge, Shuhada Bridge, Aziziyah, Kut, Amarah,
Table 3 Tributary of Tigris within Iraq (FAO 2009; AlAnsari 2013)

\begin{tabular}{llcl}
\hline Tributary & Location of confluence & Contribution $\left(\mathrm{m}^{3} / \mathrm{s}\right)$ & Catchment of the tributary km ${ }^{2}$ \\
\hline Khabur & South Khabur & 63 & No data \\
Greater Zab & 60 km downstream Mosul & 418 & 25,810 \\
Lesser Zab & Fatha & 227 & 21,475 \\
Adhaim & Adhaim & 800 & 13,000 \\
Diyala & South Baghdad & 182 & 31,896 \\
\hline
\end{tabular}


Table 4 Dams on Tigris River (Frenken 2009; Al-Ansari 2013)

\begin{tabular}{lllllll}
\hline Dam, (River) & Use & Year & Height $(\mathrm{m})$ & Storage capacity BCM & Water surface area $\left(\mathrm{km}^{2}\right)$ & Hydropower $(\mathrm{MW})^{2}$ \\
\hline Al-Adheem (Adeeem) & HP, I & 1999 & - & 1.5 & - & - \\
Derbendikhan (Diyala) & I & 1961 & 128 & 3 & 32 & - \\
Diddis (Lesser Zab) & I & 1965 & 22 & 3 & - & - \\
Diyala (Diyala) & I & 1969 & 12 & - & 270 & 400 \\
Dokan (Lesser Zab) & HP, I & 1959 & 116.6 & 6.8 & 450 & 50 \\
Hamrin (Diyala) & I, FC & 1981 & 40 & 3.56 & 380 & 750 \\
Mosul (Tigris) & HP, I, FC & 1986 & 131 & 12.5 & 2170 & 87 \\
Samarra-Tharthar (Tigris) & FD, I, HP & 1956 & - & 72.8 & \\
\hline
\end{tabular}

and Qurnah), while the stations of predicting values were (Shraqat, Tarmiyah, and Ali Garbi) (Fig. 3).

Tables 5 and 6 show the locations, the distances along Tigris River between the stations, and its coordinates, in addition to the concentrations for the selected parameters in the wet and dry seasons in 2016 were taken from National Center of Water Resources Management ( 2017) and Consulting Engineering Bureau of Baghdad University ( 2017). These parameters are calcium $(\mathrm{Ca})$, magnesium $(\mathrm{Mg})$, sodium $(\mathrm{Na})$, potassium $(\mathrm{K})$, chloride $(\mathrm{Cl})$, sulphate $\left(\mathrm{SO}_{4}\right)$, bicarbonate $\left(\mathrm{HCO}_{3}\right)$, total hardness (Th), total dissolved solids (TDS), $\mathrm{BOD}_{5}$, nitrate $\left(\mathrm{NO}_{3}\right)$, and electric conductivity $(\mathrm{EC})$.

\section{GIS prediction maps using the interpolation method}

ArcGIS 10.5 software was used to create the maps of the water quality index for 12 parameters within the Tigris River. The interpolation method inverse distance weighted (IDW) was used to generate the interpolation map for each parameter in the wet and dry seasons within the Tigris River. The interpolation in GIS software was done based on the shapefiles' maps of the Iraqi boundary and Tigris River. The IDW is a technique that reflects principally the first law of Waldo Tobler in geography (Hengl 2009). The IDW method is depended on a technique of accurate local deterministic interpolation
Fig. 2 Schematic diagram for research methodology

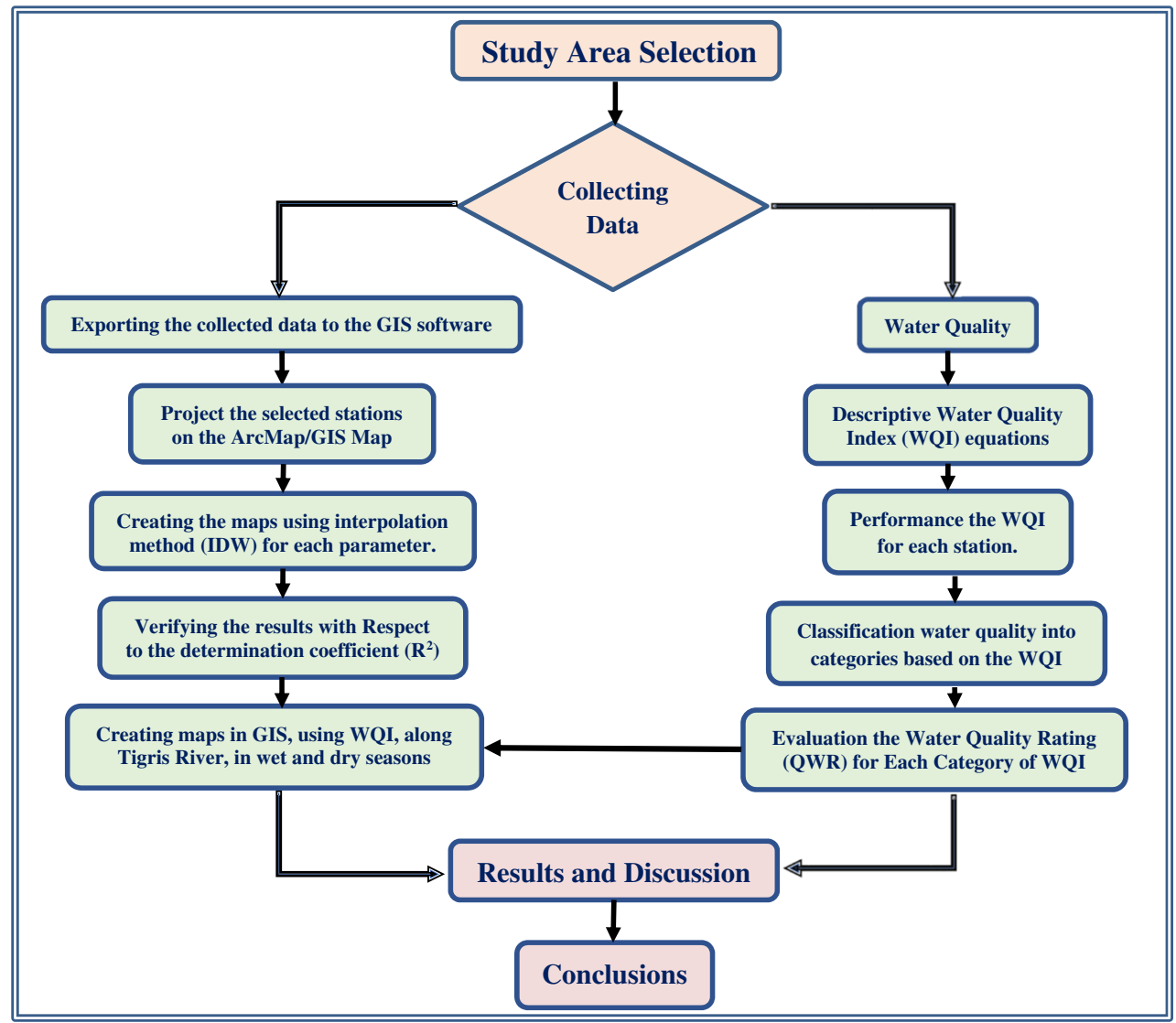




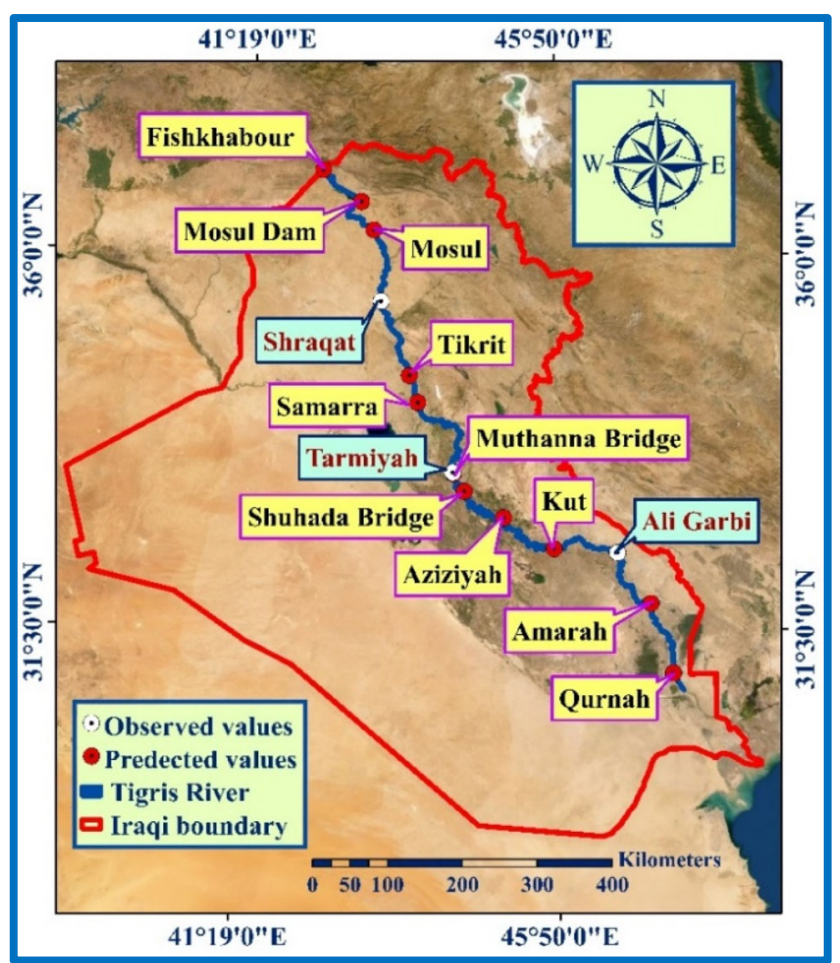

Fig. 3 Tigris River and sampling stations within Iraq

(Watson and Philip 1985). The interpolation method (IDW) is used to estimate the unknown values at a specific location as an average value of distance at known to neighboring locations, which are surrounding the unknown points (Longley et al. 2005). In the IDW, the points nearer to the prediction location will have a greater effect on the predicted values than the points that are located farther away from them (Chang 2006; Panhalkar and Jarag 2015). This procedure was applied in this study to produce interpolation between the selected points or locations using the IDW method within the range of minimum and maximum values for each parameter.

According to Panhalkar and Jarag (2015), the IDW method is considered more suitable than other methods (e.g., kriging and Topo to raster), where these methods generate an interpolation for the selected points with more deviation. The interpolation method IDW has adopted the following mathematical Eq. (1) (Panhalkar and Jarag 2015):

$\mathrm{Z}_{0}=\frac{\sum_{i=1}^{n} Z_{i} \frac{1}{X_{i}^{r}}}{\sum_{i=1}^{n} \frac{1}{X_{i}^{r}}}$

Where $Z_{\mathrm{o}}$ is the estimated value of point zero, $Z_{\mathrm{i}}$ is the $Z$ value of known point $i, X_{\mathrm{i}}$ is that distance between point $i$ and zero point, $\boldsymbol{N}$ is the number of known points used in estimation, and $r$ is the specified power $>1$.

\section{Calculating and equation of water quality index}

In this study, the method of weighted arithmetic is employed to calculate the water quality index (WQI). Twelve parameters (Ca, $\mathrm{Mg}, \mathrm{Na}, \mathrm{K}, \mathrm{Cl}, \mathrm{SO}_{4}, \mathrm{HCO}_{3}$, Th, TDS, $\mathrm{BOD}_{5}, \mathrm{NO}_{3}$, and

Table 5 Parameters concentrations along Tigris River in the wet season (2016) (NCWRM 2017; CEB 2017)

\begin{tabular}{|c|c|c|c|c|c|c|c|c|c|c|c|c|c|c|c|c|}
\hline Symbol & Station & Distance $(\mathrm{km})$ & $\mathrm{X}$ & $\mathrm{Y}$ & $\mathrm{Ca}$ & $\mathrm{Mg}$ & $\mathrm{Na}$ & K & $\mathrm{Cl}$ & $\mathrm{SO}_{4}$ & $\mathrm{HCO}_{3}$ & $\mathrm{TH}$ & TDS & $\mathrm{BOD}_{5}$ & $\mathrm{NO}_{3}$ & $\mathrm{EC}$ \\
\hline St.1 & Fishkhabour & 0 & 266,102 & $4,104,412$ & 75 & 50 & 30 & 5.3 & 32 & 353 & 196 & 712 & 443 & 3.1 & 5.7 & 682 \\
\hline St. 2 & Mosul Dam & 81.8 & 316,791 & $4,061,850$ & 80 & 58 & 45 & 5.5 & 38 & 382 & 198 & 762 & 500 & 3.2 & 6.2 & 769 \\
\hline St.3 & Mosul & 168.3 & 332,982 & $4,023,924$ & 86 & 60 & 50 & 5.9 & 52 & 403 & 196 & 804 & 575 & 3.4 & 6.8 & 885 \\
\hline Predicted $(\mathrm{P})$ & Shraqat & 295.5 & 342,773 & $3,929,097$ & 88 & 62 & 54 & 6.3 & 64 & 415 & 195 & 831 & 650 & 3.5 & 7.1 & 1000 \\
\hline St. 4 & Tikrit & 431.2 & 380,372 & $3,829,949$ & 90 & 64 & 58 & 6.7 & 74 & 426 & 193 & 855 & 725 & 3.5 & 7.5 & 1115 \\
\hline St.5 & Samarra & 473.9 & 391,570 & $3,794,163$ & 92 & 66 & 65 & 6.7 & 88 & 442 & 192 & 888 & 730 & 3.8 & 8 & 1123 \\
\hline Predicted $(\mathrm{P})$ & Tarmiyah & 650.5 & 438,111 & $3,700,862$ & 93 & 66 & 77 & 6.8 & 105 & 450 & 187 & 908 & 764 & 4.1 & 8.9 & 1175 \\
\hline St.6 & Muthanna Bridge & 652.6 & 439,145 & $3,699,016$ & 94 & 70 & 88 & 6.9 & 120 & 464 & 183 & 941 & 800 & 4.3 & 9.5 & 1231 \\
\hline St.7 & Shuhada Bridge & 701.4 & 453,880 & $3,675,739$ & 95 & 74 & 94 & 6.9 & 145 & 468 & 180 & 972 & 850 & 4.5 & 10.2 & 1308 \\
\hline St. 8 & Aziziyah & 828.1 & 506,020 & $3,640,265$ & 96 & 77 & 100 & 7.1 & 180 & 474 & 176 & 1014 & 900 & 4.8 & 11.1 & 1385 \\
\hline St.9 & Kut & 976.7 & 573,481 & $3,599,129$ & 98 & 88 & 110 & 7.4 & 220 & 478 & 176 & 1072 & 960 & 5.1 & 12.1 & 1477 \\
\hline Predicted $(\mathrm{P})$ & Ali Garbi & 1105.3 & 658,264 & $3,593,945$ & 104 & 90 & 132 & 7.9 & 270 & 484 & 174 & 1136 & 1160 & 5.5 & 14.1 & 1785 \\
\hline St.10 & Amarah & 1236.0 & 702,802 & $3,526,406$ & 109 & 92 & 150 & 8.2 & 326 & 496 & 172 & 1211 & 1356 & 5.9 & 15.9 & 2086 \\
\hline St.11 & Qurnah & 1374.9 & 732,823 & $3,433,509$ & 110 & 95 & 170 & 8.4 & 360 & 517 & 168 & 1267 & 1394 & 6.9 & 17.1 & 2145 \\
\hline \multicolumn{5}{|c|}{ Standard value (WHO 2006) } & 200 & 200 & 200 & 10 & 250 & 250 & 126 & 200 & 500 & 5 & 10 & 1000 \\
\hline \multicolumn{5}{|l|}{ Average } & 94 & 72 & 87 & 6.9 & 148 & 447 & 185 & 955 & 843 & 4.4 & 10.0 & 1298 \\
\hline \multicolumn{5}{|l|}{ S.D. } & 10 & 14 & 42 & 0.9 & 108 & 46 & 10 & 167 & 292 & 1.1 & 3.6 & 449 \\
\hline \multicolumn{5}{|l|}{ Max. } & 110 & 95 & 170 & 8.4 & 360 & 517 & 198 & 1267 & 1394 & 6.9 & 17.1 & 2145 \\
\hline \multicolumn{5}{|l|}{ Min. } & 75 & 50 & 30 & 5.3 & 32 & 353 & 168 & 712 & 443 & 3.1 & 5.7 & 682 \\
\hline
\end{tabular}


Table 6 Parameters concentrations along Tigris River in the dry season (2016) (NCWRM 2017; CEB 2017)

\begin{tabular}{|c|c|c|c|c|c|c|c|c|c|c|c|c|c|c|c|c|}
\hline Symbol & Station & Distance $(\mathrm{km})$ & $\mathrm{X}$ & $\mathrm{Y}$ & $\mathrm{Ca}$ & $\mathrm{Mg}$ & $\mathrm{Na}$ & $\mathrm{K}$ & $\mathrm{Cl}$ & $\mathrm{SO}_{4}$ & $\mathrm{HCO}_{3}$ & $\mathrm{TH}$ & TDS & $\mathrm{BOD}_{5}$ & $\mathrm{NO}_{3}$ & $\mathrm{EC}$ \\
\hline St.1 & Fishkhabour & 0 & 266,102 & $4,104,412$ & 79 & 54 & 34 & 5.1 & 33 & 360 & 194 & 726 & 438 & 3.2 & 5.9 & 674 \\
\hline St. 2 & Mosul Dam & 81.8 & 316,791 & $4,061,850$ & 86 & 62 & 49 & 5.4 & 39 & 390 & 194 & 777 & 490 & 3.3 & 6.4 & 754 \\
\hline St. 3 & Mosul & 168.3 & 332,982 & $4,023,924$ & 90 & 66 & 56 & 5.6 & 54 & 412 & 193 & 822 & 560 & 3.5 & 7 & 862 \\
\hline Predicted $(\mathrm{P})$ & Shraqat & 295.5 & 342,773 & $3,929,097$ & 93 & 69 & 70 & 6.0 & 66 & 425 & 192 & 852 & 634 & 3.6 & 7.4 & 975 \\
\hline St. 4 & Tikrit & 431.2 & 380,372 & $3,829,949$ & 94 & 70 & 65 & 6.4 & 78 & 434 & 191 & 875 & 710 & 3.6 & 7.8 & 1092 \\
\hline St.5 & Samarra & 473.9 & 391,570 & $3,794,163$ & 98 & 73 & 73 & 6.5 & 92 & 451 & 190 & 912 & 720 & 3.9 & 8.3 & 1108 \\
\hline Predicted (P) & Tarmiyah & 650.5 & 438,111 & $3,700,862$ & 102 & 75 & 86 & 6.5 & 110 & 462 & 184 & 942 & 755 & 4.2 & 9 & 1162 \\
\hline St.6 & Muthanna Bridge & 652.6 & 439,145 & $3,699,016$ & 106 & 78 & 98 & 6.6 & 128 & 472 & 180 & 974 & 790 & 4.5 & 9.6 & 1215 \\
\hline St.7 & Shuhada Bridge & 701.4 & 453,880 & $3,675,739$ & 108 & 81 & 105 & 6.7 & 158 & 478 & 177 & 1012 & 844 & 4.6 & 10.4 & 1298 \\
\hline St. 8 & Aziziyah & 828.1 & 506,020 & $3,640,265$ & 110 & 86 & 112 & 6.9 & 190 & 485 & 174 & 1056 & 890 & 5.0 & 11.3 & 1369 \\
\hline St.9 & Kut & 976.7 & 573,481 & $3,599,129$ & 112 & 96 & 120 & 7.2 & 230 & 492 & 173 & 1115 & 952 & 5.2 & 12.4 & 1465 \\
\hline Predicted $(\mathrm{P})$ & Ali Garbi & 1105.3 & 658,264 & $3,593,945$ & 115 & 100 & 143 & 7.6 & 284 & 500 & 172 & 1185 & 1152 & 5.6 & 14.2 & 1772 \\
\hline St.10 & Amarah & 1236.0 & 702,802 & $3,526,406$ & 118 & 105 & 165 & 8.0 & 338 & 508 & 170 & 1255 & 1348 & 6.0 & 16 & 2074 \\
\hline St.11 & Qurnah & 1374.9 & 732,823 & $3,433,509$ & 122 & 110 & 190 & 8.2 & 370 & 530 & 164 & 1313 & 1385 & 7.1 & 17.3 & 2131 \\
\hline \multicolumn{5}{|c|}{ Standard value (WHO 2006) } & 200 & 200 & 200 & 10 & 250 & 250 & 126 & 200 & 500 & 5 & 10 & 1000 \\
\hline \multicolumn{5}{|l|}{ Average } & 102 & 80 & 98 & 6.6 & 155 & 457 & 182 & 987 & 833 & 4.5 & 10.2 & 1282 \\
\hline \multicolumn{5}{|l|}{ S.D. } & 13 & 17 & 45 & 0.9 & 112 & 48 & 10 & 179 & 293 & 1.1 & 3.6 & 450 \\
\hline \multicolumn{5}{|l|}{ Max. } & 122 & 110 & 190 & 8.2 & 370 & 530 & 194 & 1313 & 1385 & 7.1 & 17.3 & 2131 \\
\hline \multicolumn{5}{|l|}{ Min. } & 79 & 54 & 34 & 5.1 & 33 & 360 & 164 & 726 & 438 & 3.2 & 5.9 & 674 \\
\hline
\end{tabular}

EC) were used to determine the WQI for the selected fourteen stations along the Tigris River because these parameters are so significant to calculate the water quality index for different purposes. The WQI for each selected station in the Tigris River was calculated using the following Eqs. (2), (3), and (4) (Tyagi et al. 2013):

$Q \mathrm{i}=\left(\frac{N_{\mathrm{i}}-N_{0}}{\mathrm{ST}_{\mathrm{i}}-N_{0}}\right) \times 100$

$W \mathrm{i}=\frac{1}{S T_{i}}$

$\mathrm{WQI}=\frac{\sum Q i \times W i}{\sum W i}$

Where $Q_{\mathrm{i}}$ is the sub-index of the $i$ th parameter, $W \mathrm{i}$ is the inverse weight of the standard value $\left(\mathrm{ST}_{\mathrm{i}}\right)$ of the $i$ th parameter, $\mathrm{ST}_{\mathrm{i}}$ is the standard value of the $i$ th parameter (WHO 2006), $N_{\mathrm{i}}$ is the measured concentration value for the $i$ th parameter, and $N_{0}$ is the ideal value for each parameter in water that has zero value, excluding the dissolved oxygen and $\mathrm{pH}$ values which are equal to $14.6 \mathrm{ppm}$ and 7 respectively.

For each station along the Tigris River, the water quality rating (QWR) was given the deserve classification based on the category of the WQI according to Alsaqqar et al. (2015) and Ali (2017) (see Table 7).

\section{Results and discussion}

This section is divided into three parts depending on the methodology used approach. These parts are concentration values of parameters measured in the selected stations, GIS maps, and WQI.

\section{Concentration values of parameters in the selected stations}

The results of the physicochemical parameters analyzed in all the sampling locations during the wet season and dry season are shown in Tables 6 and 7, respectively.

The variations of $\mathrm{Ca}$ along the Tigris River in the wet season ranged from 110 to $75 \mathrm{mg} / \mathrm{L}$ at stations (11) and (1) respectively, and the average value of $\mathrm{Ca}$ concentration in this season was $94 \mathrm{mg} / \mathrm{L}$. In the dry season, the maximum and minimum values (in mg/L) were 122 (station 11) and 79 (station 1) respectively and the average value in this season was $102 \mathrm{mg} / \mathrm{L}$. For the concentrations of $\mathrm{Ca}$ and $\mathrm{Mg}$, the values measured during the dry season were higher than the values in the wet season at all selected stations along the Tigris River. Figure $4 \mathrm{a}$, b shows that the measured values of $\mathrm{Ca}$ and $\mathrm{Mg}$ in both seasons increased from the station (1) in Fishkhabour (Dohuk province) to the station (11) in Qurnah (Al-Basra province).

The average concentrations of $\mathrm{Mg}$ measured in Tigris River during dry and wet seasons were 72 and $80 \mathrm{mg} / \mathrm{L}$ 
Table 7 Water quality rating classification based on WQI value (Alsaqqar et al. 2015; Ali 2017)

\begin{tabular}{ll}
\hline Value of WQI & Water quality rating (QWR) \\
\hline$<50$ & Excellent \\
$50-100$ & Good \\
$100-200$ & Poor \\
$200-300$ & Very poor \\
$300-400$ & Polluted \\
$>400$ & Vary polluted \\
\hline
\end{tabular}

respectively. The highest and lowest reading of $\mathrm{Mg}$ concentration during wet and dry seasons ranged from $(95-110) \mathrm{mg} /$ $\mathrm{L}$ at the station (11) to (50-54) $\mathrm{mg} / \mathrm{L}$ at the station (1) respectively (Fig. 4b). The values of samples for $\mathrm{Ca}$ and $\mathrm{Mg}$, which were taken from a series of stations within the Tigris River, were less than the permissible limit of $200 \mathrm{mg} / \mathrm{L}$ (Chang 2006).

During the wet season, the sodium $(\mathrm{Na})$ concentration ranged from $170 \mathrm{mg} / \mathrm{L}$ at (St.11) to $30 \mathrm{mg} / \mathrm{L}$ at (St.1) and the average value was $87 \mathrm{mg} / \mathrm{L}$. The concentration of $\mathrm{Na}$ during the dry season ranged from $190 \mathrm{mg} / \mathrm{L}$ at (St.11) to $34 \mathrm{mg} / \mathrm{L}$ at (St.1), while the average value during this season was $98 \mathrm{mg} / \mathrm{L}$. The measured samples of sodium (Na) concentrations showed that all values were less than the allowable limit of $200 \mathrm{mg} / \mathrm{L}$ (Chang 2006).

Potassium (K) concentration during the wet season varied from the maximum value of $8.4 \mathrm{mg} / \mathrm{L}$ (station 11) to the minimum value of $5.3 \mathrm{mg} / \mathrm{L}$ (station 1) with an average value of $6.9 \mathrm{mg} / \mathrm{L}$. The lowest reading of $\mathrm{K}$ during the dry season was $5.1 \mathrm{mg} / \mathrm{L}$ at the station (1) and the highest value was recorded $8.2 \mathrm{mg} / \mathrm{L}$ at the station (11) with an average value of $6.6 \mathrm{mg} / \mathrm{L}$. The results of measured potassium were lower than the allowable limit of $10 \mathrm{mg} / \mathrm{L}$ (Chang 2006).

The values of the $\mathrm{Na}$ concentrations in the dry season were higher than the values in the wet season at all stations, while the values of $\mathrm{Na}$ concentrations in the dry season were less than the values in the wet season. The readings of $\mathrm{Na}$ (Fig. 5a) and $\mathrm{K}$ (Fig. 5b) increased from the station (1) toward the station (11).

The maximum values of chloride $(\mathrm{Cl})$ concentration during wet and dry seasons were 360 and $370 \mathrm{mg} / \mathrm{L}$ respectively at station 11 , and the average values were 148 and $155 \mathrm{mg} / \mathrm{L}$ in both wet and dry seasons respectively. During both dry and wet seasons, the lowest value of chloride was 32 and $33 \mathrm{mg} / \mathrm{L}$ at the station (1). The entire values of $\mathrm{Cl}$ concentrations which were measured along the Tigris River were lower than the allowable limit of $250 \mathrm{mg} / \mathrm{L}$ in both wet and seasons (Chang 2006).

Sulphate $\left(\mathrm{SO}_{4}\right)$ concentrations during wet season varied between (517-353) $\mathrm{mg} / \mathrm{L}$ at the stations (11 and 1) respectively with an average value of $447 \mathrm{mg} / \mathrm{L}$. The concentrations of sulphate during the dry season ranged from $530 \mathrm{mg} / \mathrm{L}$ at the station (11) to $360 \mathrm{mg} / \mathrm{L}$ at the station (1) and the average value of sulphate concentration along Tigris River was $457 \mathrm{mg} / \mathrm{L}$. The values of $\mathrm{SO}_{4}$ concentrations measured at selected stations along the Tigris River were over the allowable limit of $250 \mathrm{mg} /$ L during wet and dry seasons (Chang 2006).

The values of $\mathrm{Cl}$ (Fig. 6a) and $\mathrm{SO}_{4}$ (Fig. 6b) were increased from the upstream of the Tigris River in the north of Iraq at the station (1) toward the south of Iraq (downstream of the river) at the station (11). The values of $\mathrm{Cl}$ and $\mathrm{SO}_{4}$ concentrations in the wet season were lower than the values in the dry season at the selected stations along the Tigris River.

For the TDS and EC, the readings during the wet season were found at stations (1 and 11) with a range of (443-1394) $\mathrm{mg} / \mathrm{L}$ and (682-2145) $\mu \mathrm{mhos} / \mathrm{cm}$ respectively. The readings for TDS and EC during the dry season were ranged between 438 and $1385 \mathrm{mg} / \mathrm{L}$ and between 674 and $2131 \mu \mathrm{mhos} / \mathrm{cm}$ at stations (11 and 1) respectively. The average values during the wet season for TDS were $843 \mathrm{mg} / \mathrm{L}$ and $833 \mathrm{mg} / \mathrm{L}$ during the dry season, while for $\mathrm{EC}$, the average values during wet and dry seasons were $1298 \mu \mathrm{mhos} / \mathrm{cm}$ and $1282 \mu \mathrm{mhos} / \mathrm{cm}$ respectively. In the current study, during wet and dry seasons at the selected stations along Tigris River, the readings of total dissolved solids (TDS) were higher than the allowable limit of $500 \mathrm{mg} / 1$ except the values recorded at stations (1 and 2) which were within the allowable limit. The readings of the EC were more than the upper allowable limit of 1000 $\mu \mathrm{mhos} / \mathrm{cm}$ (WHO 2006) except the values measured at stations (1-4) which were lower than the allowable limit. Figure $7 \mathrm{a}$ and $\mathrm{b}$ shows the values of TDS and EC decreased from the station (1) in Fishkhabour in the north of Iraq toward station (11) in the Qurnah in the south of Iraq. The readings of $\mathrm{Cl}$ and $\mathrm{SO}_{4}$ concentrations in the wet season were more than
Fig. 4 Concentrations of a $\mathrm{Ca}$ and $\mathbf{b} \mathrm{Mg}$ in the wet and dry seasons along Tigris River

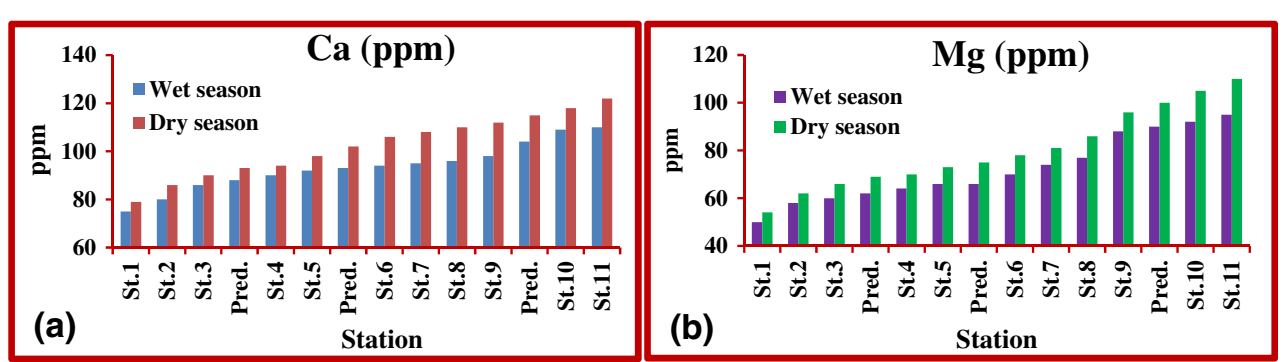


Fig. 5 Concentrations of a $\mathrm{Na}$ and $\mathbf{b} \mathrm{K}$ in the wet and dry seasons along Tigris River

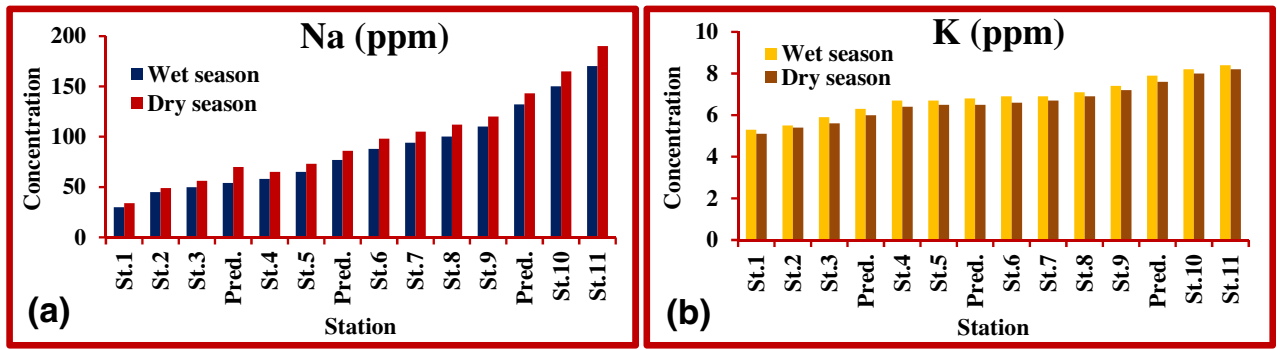

the readings in the dry season along the River at the selected stations.

In this study, along Tigris River, the highest concentrations of total hardness $(\mathrm{TH})$ during wet and dry seasons were equal to 1267 and $1313 \mathrm{mg} / \mathrm{L}$ at the station (11) respectively. The lowest values of TH were 712 and $726 \mathrm{mg} / \mathrm{L}$ during wet and dry seasons respectively, and these values were recorded at the station (1). Along the Tigris River in both seasons (wet and dry), the average values were 955 and $987 \mathrm{mg} / \mathrm{L}$ respectively. Along the Tigris River, all the readings of TH recorded during wet and dry seasons were higher than the upper allowable limit $(200 \mathrm{mg} / \mathrm{L})$ (WHO 2006). The values of TH concentrations were increased from station (1) along Tigris River to the station (11), and the readings of TH during the dry season were more than the readings in the wet season at the chosen stations (Fig. 8a).

The maximum values of bicarbonate $\left(\mathrm{HCO}_{3}\right)$ during wet and dry seasons were 198 and $195 \mathrm{mg} / \mathrm{L}$ respectively at the station (2). The minimum value of bicarbonate concentration during the wet season was $168 \mathrm{mg} / \mathrm{L}$ and during the dry season was $164 \mathrm{mg} / \mathrm{L}$. These values were recorded at the station (11). The average values during the wet and dry seasons were $185 \mathrm{mg} / \mathrm{L}$ and $182 \mathrm{mg} / \mathrm{L}$ respectively. In this study, all measured values of $\mathrm{HCO}_{3}$ along the Tigris River were higher than the maximum allowable limit (126 mg/L) (WHO 2006). Figure $8 \mathrm{~b}$ showed that the readings of $\mathrm{HCO}_{3}$ concentrations during the wet season were higher than the readings in the dry season at all selected stations. Moreover, the linear trendline along the Tigris River of bicarbonate concentration values in Fig. $8 \mathrm{~b}$ dropped from the station (1) toward the station (11).

The variations in concentrations of $\mathrm{HCO}_{3}$ at the stations of the Tigris River are due to the difference in the rates of rainfall and the $\mathrm{pH}$ value. Carbon dioxide (one of the main compounds of $\mathrm{HCO}_{3}$ ) has the ability to decomposition and combining with other elements, where the reaction of $\mathrm{CO}_{2}$ with water of rain and atmospheric gases leads to change $\mathrm{HCO}_{3}$ concentrations from station to other (Al-Shemari and Abdulhussain 2013).

The values of $\mathrm{BOD}_{5}$ varied from $3.1 \mathrm{mg} / \mathrm{L}$ (1) to $6.9 \mathrm{mg} / \mathrm{L}$ (11) with the average of $4.4 \mathrm{mg} / \mathrm{L}$ during the wet season, and between $(3.2-7.1) \mathrm{mg} / \mathrm{L}$ at stations (1 and 11) respectively during the dry season with the mean value of $4.5 \mathrm{mg} / \mathrm{L}$. The values recorded at stations (9-11) and the predicted station (Ali Garbi) were more than the maximum allowable limit $\left(5 \mathrm{mg} / \mathrm{L}\right.$ ) in both seasons (WHO 2006). The values of BOD $_{5}$ concentrations were increased from the upstream of the Tigris River at the station (1) toward station (11) in Al-Basrah province. The values of $\mathrm{BOD}_{5}$ concentrations in the wet season were lower than the values in the dry season at the chosen stations along the Tigris River (Fig. 9a).

The average values of nitrate $\left(\mathrm{NO}_{3}\right)$ during wet and dry seasons were $10 \mathrm{mg} / \mathrm{L}$ and $10.2 \mathrm{mg} / \mathrm{L}$ respectively. The minimum values were $5.7 \mathrm{mg} / \mathrm{L}$ and $5.9 \mathrm{mg} / \mathrm{L}$ at the station (1) during wet and dry seasons, while the maximum values of $\mathrm{NO}_{3}$ were 17.1 and 17.3 , and these readings were observed at the station (11). The maximum values were higher than the maximum allowable limit (10 mg/L) (WHO 2006).

The values of $\mathrm{NO}_{3}$ concentrations were increased from station to next station starting from the upstream of Tigris River in the north of Iraq at the station (1) toward station (11) that is located in the south of Iraq (Fig. 9b). The values of $\mathrm{NO}_{3}$ concentrations in the wet season were more than the values in the dry season along the Tigris River at the selected stations.

In summary, the maximum and minimum concentration values of 12 parameters measured at the selected stations along the Tigris River in the wet and dry seasons in the year 2016 are listed in Table 8.
Fig. 6 Concentrations of $\mathbf{a ~} \mathrm{Cl}$ and b $\mathrm{SO}_{4}$ in the wet and dry seasons along Tigris River

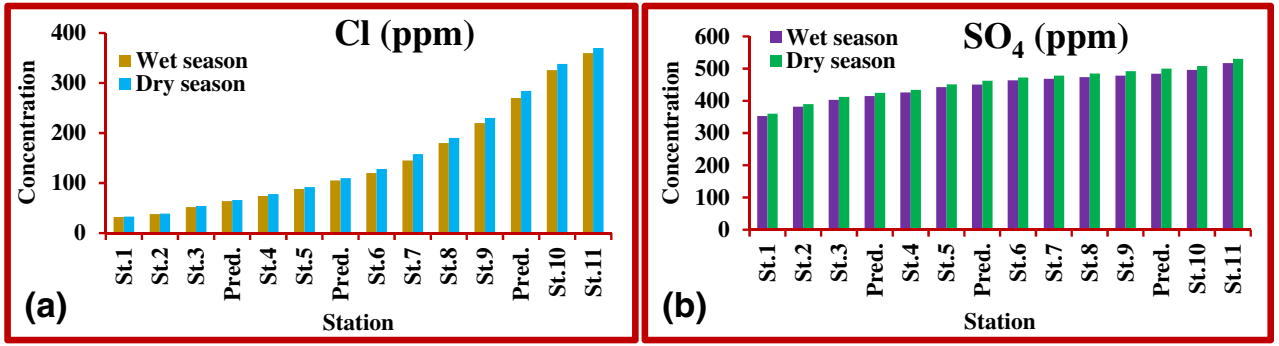


Fig. 7 Concentrations of $\mathrm{a} \mathrm{Cl}$ and b $\mathrm{SO}_{4}$ in the wet and dry seasons along Tigris River

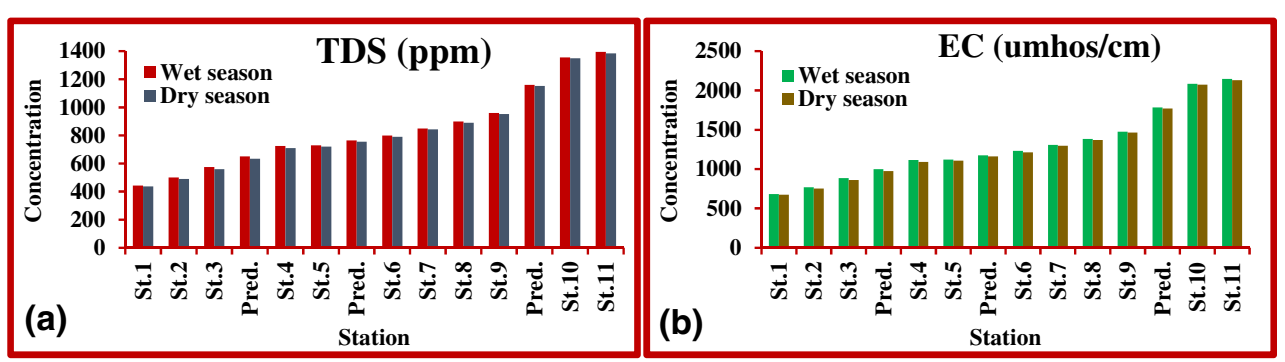

The maximum values for the selected parameters were recorded in the station 11 (Qurnah) due to the reason mentioned in item 5; moreover, this station is considered the end station at the Tigris River and the parameters with high concentration moving from previous stations to this station and water level of the river at the station (11) is low compared with the other stations along Tigris River. The minimum values were recorded at the station (1) because there are not irrigation projects before and, around this station, where that the river passes through mountain area before entering the Iraqi borders at the station (1) in Fishkhabour. Moreover, there are a few cities that exist on both banks of the river located outside the Iraqi borders before reaching the station (1). Major cities with dense population increase after station (1) toward the station (11) which represents that the downstream of the river have significant effects on the quality of the Tigris River system.

\section{Prediction maps}

In this study, the prediction maps for 12 physical and chemical parameters measured from a series of stations along the Tigris River were produced in the wet and dry seasons in 2016. Eleven stations were used to generate prediction maps using the interpolation method (IDW) and ArcGIS (10.5) software. These maps provide an indicator for the situation of the Tigris River from upstream to downstream inside the Iraqi borders using some physical and chemical parameters and enable the researchers to compare their results with the results of this work in the future. Moreover, the prediction maps provide data for the level of concentrations of parameters at each location along the Tigris River inside Iraq. The prediction maps for the wet season along the Tigris River in 2016 can be seen in Fig. 10, while Fig. 11 shows the prediction maps for the dry season along the Tigris River.

To check the values obtained from the prediction maps generated from using the interpolation method (IDW) and GIS related to Tigris River for the 12 parameters, the regression prediction was applied between 3 measured values (observed values) and predicted values (resulted from prediction maps) during the wet and dry seasons in the year 2016. The determination coefficient $\left(R^{2}\right)$ for the regression predictions between observed and predicted values for all parameters had high acceptable values as shown in Figs. 12 and 13

Several previous research applied the spatial interpolation technique (IDW) to produce the interpolation maps for the water quality of rivers rather than other techniques (e.g., Kriging and Topo to Raster), where the IDW technique was given the best and accurate results than other spatial interpolation techniques (Goff and Nordfjord 2004; Merwade et al. 2006; Merwade 2009; Meng et al. 2009; Abbas 2013; Panhalkar and Jarag 2015).

Many previous studies considered the IDW method in GIS to produce the interpolation maps of water quality for Rivers. Panhalkar and Jarag (2015) compared the spatial interpolation techniques (IDW, Kriging, and Topo to Raster) to produce the interpolation maps for the Panchganga River Basin. They selected 84 cross-sections along the river. Panhalkar and Jarag found that IDW was considered more accurate than the Kriging and Topo to Raster techniques for generating the bathymetry of the Panchganga River Basin. Abbas (2013) applied the spatial interpolation method (IDW) in the GIS to produce 17 maps for the concentrations of the selected parameters along the Tigris River in Baghdad city. OKE et al. (2013) used the IDW to generate the interpolation maps for the water quality of the Ogun sun river basin, Nigeria.
Fig. 8 Concentrations of (a): $\mathrm{TH}$ and (b): $\mathrm{HCO}_{3}$ in the wet and dry seasons along Tigris River

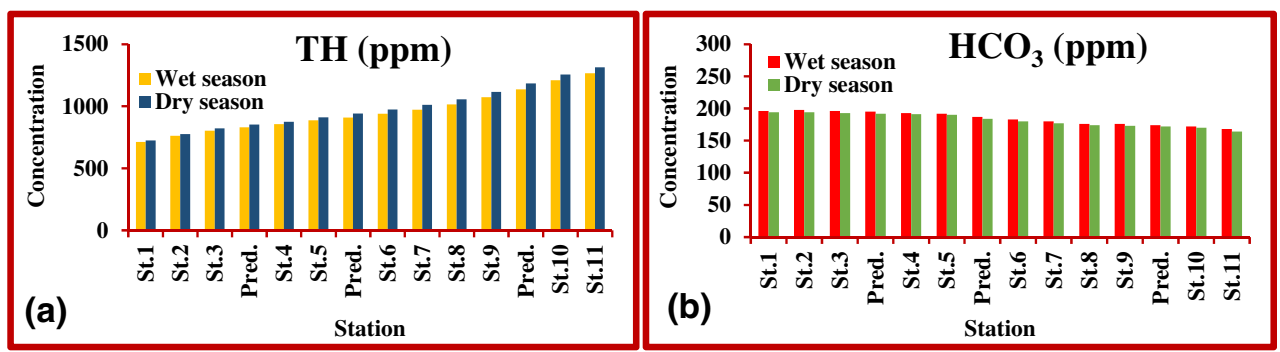


Fig. 9 Concentrations of $\mathbf{a} \mathrm{BOD}_{5}$ and $\mathbf{b} \mathrm{NO}_{3}$ in the wet and dry seasons along Tigris River

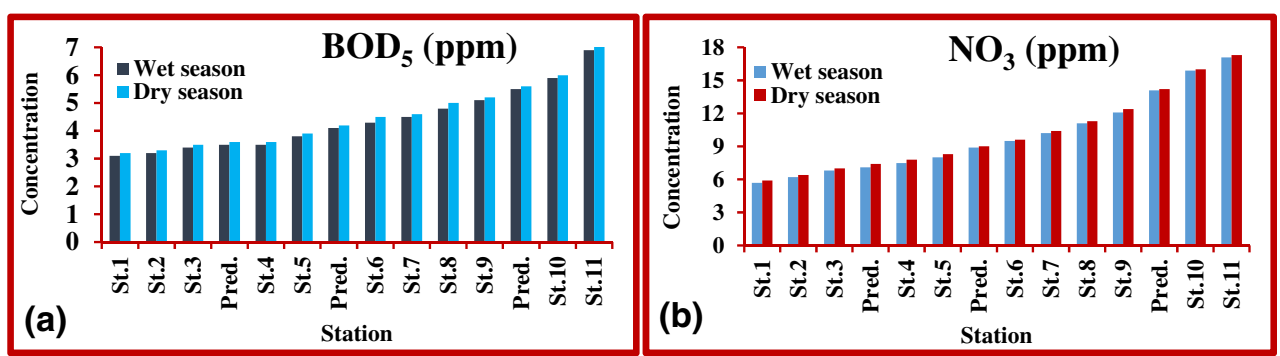

\section{Water quality index}

The method of weighted arithmetic water quality index was used to calculate the water quality index (WQI) at the selected stations along the Tigris River during wet and dry seasons in 2016 based on Eqs. (2-4). For example, the water quality index in Fishkhabour which represented the first station in the Tigris River during the wet season for the year 2016 was calculated using the weighted arithmetic water quality method (Tyagi et al. 2013) (Table 9). Then, the water quality rating (WQR) was obtained for each station (14 stations) along the Tigris River using Table 4 (Alsaqqar et al. 2015) and based on and the resulted values of the WQI. Tables 10 and 11 show the WQI and WQR for the chosen stations along the Tigris River during wet and dry seasons in 2016.

To compare the results of the present study with other former studies in this field. Several researchers have studied the water quality of the upper and lower sections of Tigris River with considerable studies on the middle part of the river at Baghdad city because this part has been identified of more municipal and industrial activities compared to the other sections of the river as it passes through the Baghdad city metropolis which is more of the urban area. Ali (2018) assessed water quality in the Tigris River using the WQI method at three selected stations (Mosul, Baghdad, and Amarah).
Ali found that the water quality index values at three selected stations (Mosul, Baghdad, and Amarah) were 121.859, 437.913, and 2219.07 in 2013; 182.96, 271.262, and 650.618 in 2014; and $193.71,227.527$, and 567.765 in 2015. The results of the WQI values in these three stations for the years (2013-2015) were higher than the values calculated in the current study. This is because Ali (2018) used the turbidity parameter in his study, where this parameter contributed to give high value for the WQI at these stations for the selected period, while the current study did not consider turbidity parameter to calculate for the WQI value because the turbidity parameter did not measure the present study. Ewaid et al. (2018) evaluated the water quality along the Tigris River inside Baghdad city, Iraq, for about $50 \mathrm{~km}$ using the annual WQI method. They measured 11 parameters from 10 stations. The results showed that the water quality for drinking was unsuitable for usable. Rabee et al. (2011) measured nine ecological parameters in Baghdad to evaluate the water quality of the Tigris River in all seasons using the WQI method. The mean output value of the WQI for all seasons was classified as a medium between good and bad and the water of Tigris River was not suitable to use for direct domestic in entire seasons. Flaieh et al. (2014) found that the water quality along the Tigris River close to Baghdad city using the WQI method was poor and not suitable for drinking, irrigation, and
Table 8 The maximum and minimum concentrations for the selected parameters and their locations in the Tigris River for wet and dry seasons

\begin{tabular}{|c|c|c|c|c|c|c|c|c|c|c|}
\hline \multirow[t]{2}{*}{ No. } & \multirow[t]{2}{*}{ Parameter } & \multirow[t]{2}{*}{ Unit } & \multicolumn{4}{|c|}{ Wet season } & \multicolumn{4}{|c|}{ Dry season } \\
\hline & & & $\begin{array}{l}\text { Max. } \\
\text { value }\end{array}$ & Station & $\begin{array}{l}\text { Min. } \\
\text { value }\end{array}$ & Station & $\begin{array}{l}\text { Max. } \\
\text { value }\end{array}$ & Station & $\begin{array}{l}\text { Min. } \\
\text { value }\end{array}$ & Station \\
\hline 1 & $\mathrm{Ca}$ & $\mathrm{mg} / \mathrm{L}$ & 110 & 11 & 75 & 1 & 122 & 11 & 79 & 1 \\
\hline 2 & $\mathrm{Mg}$ & $\mathrm{mg} / \mathrm{L}$ & 95 & 11 & 50 & 1 & 110 & 11 & 54 & 1 \\
\hline 3 & $\mathrm{Na}$ & $\mathrm{mg} / \mathrm{L}$ & 170 & 11 & 30 & 1 & 190 & 11 & 34 & 1 \\
\hline 4 & $\mathrm{~K}$ & $\mathrm{mg} / \mathrm{L}$ & 8.4 & 11 & 5.3 & 1 & 8.2 & 11 & 5.1 & 1 \\
\hline 5 & $\mathrm{Cl}$ & $\mathrm{mg} / \mathrm{L}$ & 360 & 11 & 32 & 1 & 370 & 11 & 33 & 1 \\
\hline 6 & $\mathrm{SO}_{4}$ & $\mathrm{mg} / \mathrm{L}$ & 517 & 11 & 353 & 1 & 530 & 11 & 360 & 1 \\
\hline 7 & $\mathrm{HCO}_{3}$ & $\mathrm{mg} / \mathrm{L}$ & 198 & 2 & 168 & 11 & 194 & 1,2 & 164 & 11 \\
\hline 8 & $\mathrm{TH}$ & $\mathrm{mg} / \mathrm{L}$ & 1267 & 11 & 712 & 1 & 1313 & 11 & 726 & 1 \\
\hline 9 & TDS & $\mathrm{mg} / \mathrm{L}$ & 1394 & 11 & 443 & 1 & 1385 & 11 & 438 & 1 \\
\hline 10 & BOD & $\mathrm{mg} / \mathrm{L}$ & 6.9 & 11 & 3.1 & 1 & 7.1 & 11 & 3.2 & 1 \\
\hline 11 & $\mathrm{NO}_{3}$ & $\mathrm{mg} / \mathrm{L}$ & 17.1 & 11 & 5.7 & 1 & 17.3 & 11 & 5.9 & 1 \\
\hline 12 & $\mathrm{EC}$ & umhos/cm & 2145 & 11 & 682 & 1 & 2131 & 11 & 674 & 1 \\
\hline
\end{tabular}


Fig. 10 Maps of parameters in wet season (2016) along the Tigris River using the interpolation method (IDW): (a): Ca; (b): $\mathrm{Mg}$; (c): Na; (d): K; (e): SO4; (f): TDS; (g): Cl; (h): $\mathrm{HCO} 3$; (i): $\mathrm{TH}$, (k): NO3, (l) EC and (o): BOD
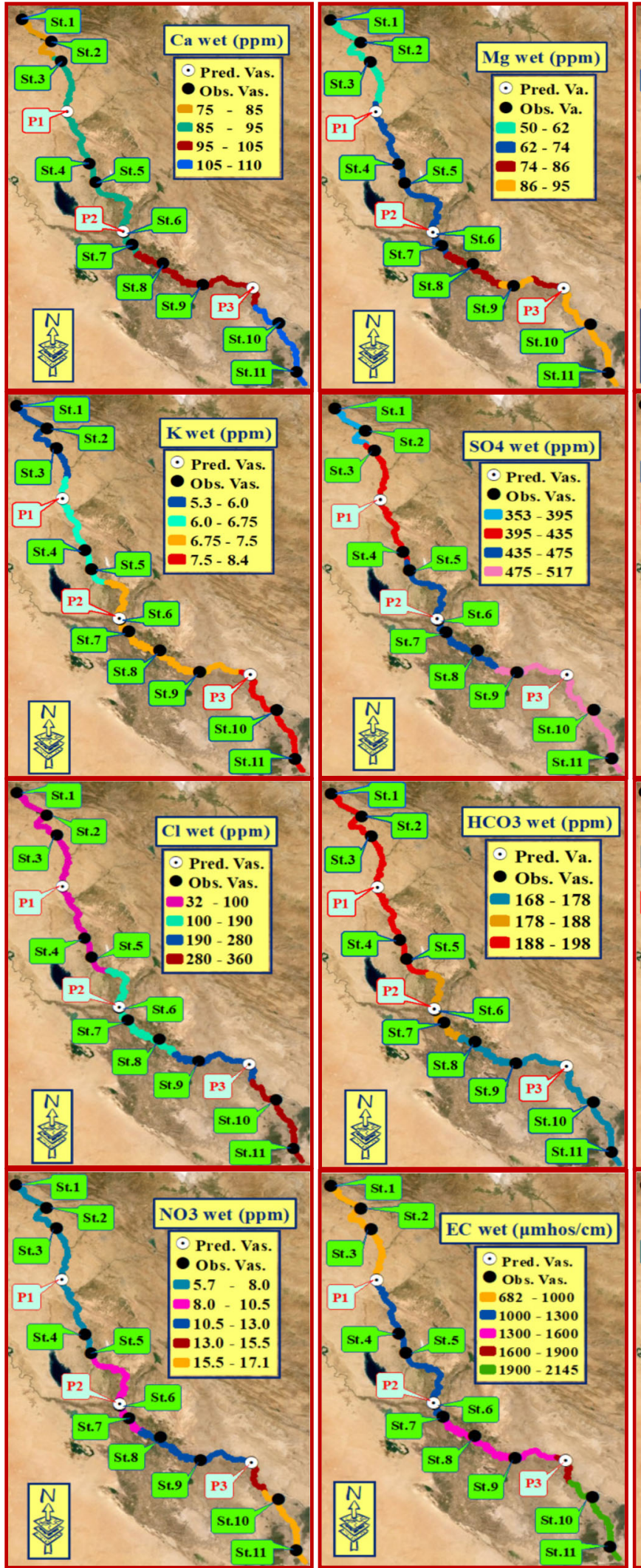

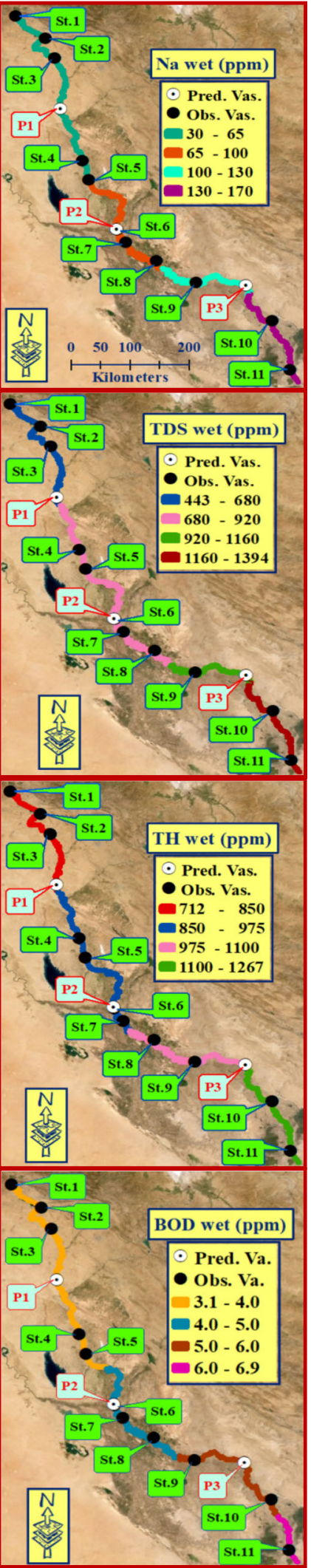

industrial uses. They measured 18 parameters from 10 stations near 8 water treatment plants. Abbas (2013) evaluated the water quality for 17 parameters at 8 stations along the Tigris River in Baghdad city, Iraq. The results showed that the 
Fig. 11 Maps of parameters in dry season (2016) along the Tigris River using the interpolation method (IDW): a Ca, b Mg, c Na, d K, e SO4, f TDS, g Cl, h HCO3, i TH, $\mathbf{k} \mathrm{NO} 3, \mathbf{l} \mathrm{EC}$, and $\mathbf{o} \mathrm{BOD}$
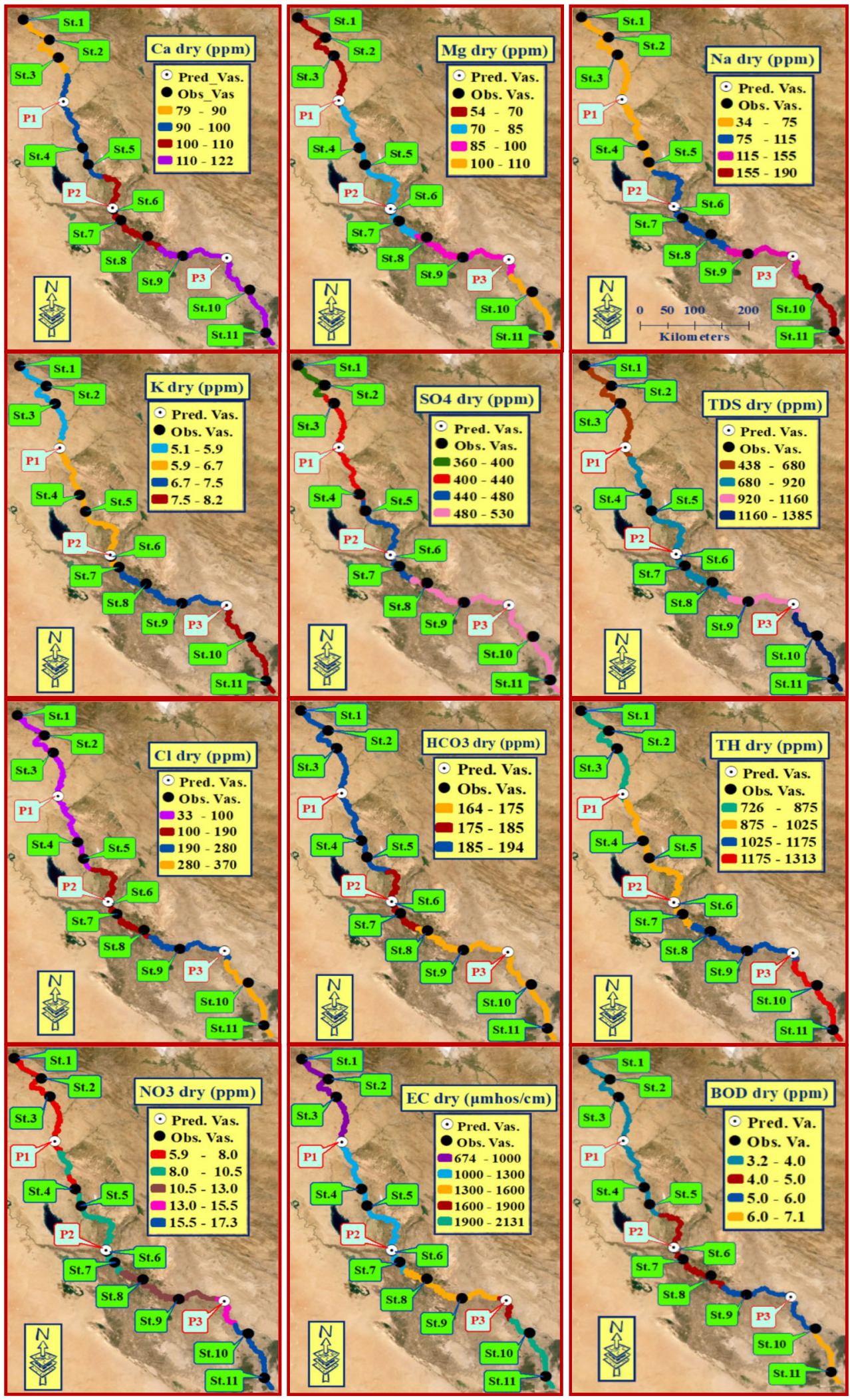

concentration of TDS, EC, TH, SO4, CL, and Fe were high while the reading of $\mathrm{pH}, \mathrm{Ca}, \mathrm{Mg}$, and $\mathrm{F}$ were within the allowable limits of WHO and Iraqi Criteria. In Al-In Amara city, Sabah (2014) assessed the water quality in the Tigris River for irrigation purposes using the WQI method. He measured nine parameters from ten stations on the river. The 
Fig. 12 Regression results in wet season (2016) between observed and predicted values

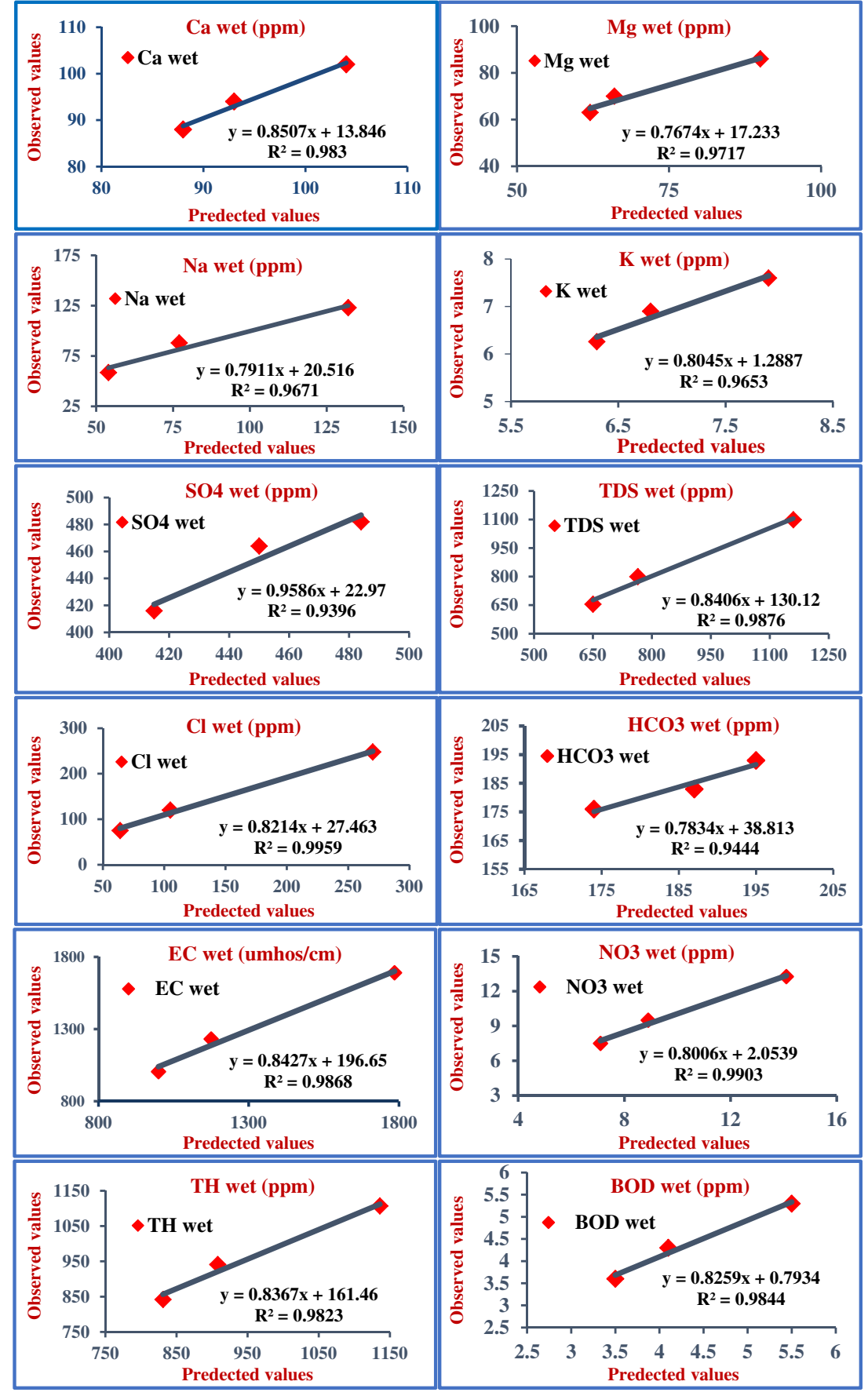

results stated that the water quality of the Tigris River in Amara city was located within the permissible limits for irrigation purposes related to the calculated indices. These researchers did not develop a water quality map of the river as it flows downstream in Iraq compared with the present study.

The water quality rating (QWR) was classified into five categories (see Table 7), according to Alsaqqar et al. (2015), based on the values of water quality index that were calculated using the method of weights of water quality index by Tyagi et al. (2013).
The values of water quality index at Fishkhabour (St. 1), Mosul Dam (St. 2), Mosul (St. 3), and Shraqat (prediction station) during wet and dry seasons in 2016 were as follows: (63.024-64.077), (66.202-67.469), (70.810$71.665)$, and (73.683-74.854) respectively. All parameters at the stations (1-4) were within allowable limits accepted $\mathrm{SO}_{4}, \mathrm{HCO}_{3}$, and total hardness (TH). The water quality values at these stations were given a good rating in both seasons which were between 50 and 100 (Alsaqqar et al. 2015; Ali 2017). 
Fig. 13 Regression results in dry season (2016) between observed and predicted values
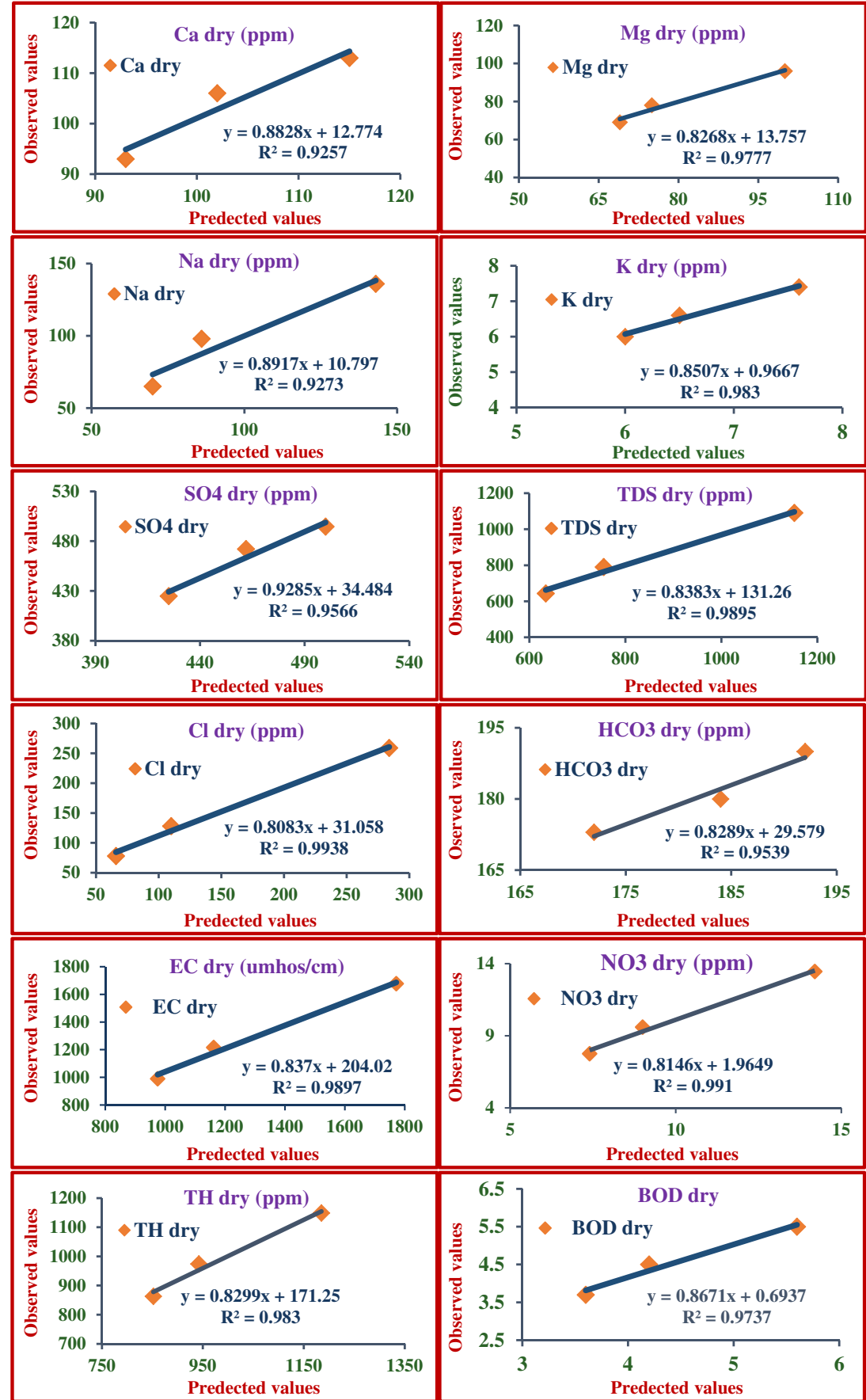

Along Tigris River at stations Tikrit (St.4), Samarra (St.5), Tarmiyah (prediction station), and Muthanna Bridge (St.6), the WQI values in the wet and dry seasons (respectively) were (75.830-76.948), (80.055-81.459), (86.044-86.878), and (89.855-91.595). The parameters $\mathrm{SO}_{4}, \mathrm{HCO}_{3}$, TDS, TH, and $\mathrm{EC}$ were higher than allowable limits at these stations and other parameters were acceptable (within allowable limits). The values of the water quality rating in these stations were good. So, the water quality was classified as a good rating based on the WQI values at these stations.
The values of the WQI were lower than 100 starting from the station (1) until the station (7) and these stations were classified as good water quality. This is due to the amount of the pollutants released into the river at these stations from different sources that did not have significant impacts on the water quality system, consequently, decreased the values of the WQI in the river. In these stations, the increasing water levels into the waterway of the river can decrease the concentrations of the parameters because the river can self-purify and then reduce the WQI values. In addition, there are no projects 
Table 9 Illustrating case of (WQI), Fishkabour station, wet season 2016 (Tyagi et al. 2013; Ali 2017)

\begin{tabular}{|c|c|c|c|c|c|c|}
\hline Parameters & $N_{\mathrm{i}}^{\mathrm{a}}$ & $\mathrm{ST}_{\mathrm{i}}^{\mathrm{b}}$ & $W_{\mathrm{i}}$ & $Q_{\mathrm{i}}$ & $\mathrm{WQ}_{\mathrm{i}}$ & \\
\hline $\mathrm{Ca}$ & 75 & 200 & 0.005 & 37.5 & 0.1875 & \\
\hline $\mathrm{Mg}$ & 50 & 200 & 0.005 & 25 & 0.125 & \\
\hline $\mathrm{Na}$ & 30 & 200 & 0.005 & 15 & 0.075 & \\
\hline K & 5.3 & 10 & 0.1 & 53 & 5.3 & \\
\hline $\mathrm{Cl}$ & 32 & 250 & 0.004 & 12.8 & 0.0512 & \\
\hline $\mathrm{SO}_{4}$ & 353 & 250 & 0.004 & 141.2 & 0.5648 & \\
\hline $\mathrm{HCO}_{3}$ & 196 & 126 & 0.0079 & 155.6 & 1.2345 & \\
\hline $\mathrm{TH}$ & 712 & 200 & 0.005 & 356 & 1.78 & \\
\hline TDS & 443 & 500 & 0.002 & 88.6 & 0.1772 & \\
\hline $\mathrm{BOD}_{5}$ & 3.1 & 5 & 0.2 & 62 & 12.4 & \\
\hline NO3 & 5.7 & 10 & 0.1 & 57 & 5.7 & \\
\hline $\mathrm{EC}$ & 682 & 1000 & 0.001 & 68.2 & 0.0682 & \\
\hline Sum & & & 0.4389 & & 27.663 & $\mathrm{WQI}=27.663 / 0.4389=63.024$ \\
\hline
\end{tabular}

${ }^{\mathrm{a}} \mathrm{N}_{\mathrm{i}}$ : the measured concentration value for the $i$ th parameter

${ }^{\mathrm{b}} \mathrm{ST}_{\mathrm{i}}$ : standard value of the $i$ th parameter (WHO 2006) of irrigation established before and, around these stations and there are a few or small cities distributed on both banks of the river which are situated outside the Iraqi boundary before the station (1). Therefore, the measured concentrations of parameters in the station (1-7) were lower than the parameters concentrations after the station (7).

At the Aziziyah station (8) in Tigris River, the values of water quality index in the wet and dry seasons were 100.327 and 101.641 respectively. These values were classified as poor within the category of (100-200) (see Table 7). The values of six parameters $\mathrm{SO}_{4}, \mathrm{HCO}_{3}$, TDS, $\mathrm{TH}, \mathrm{NO}_{3}$, and EC were upper than the allowable limits at this station and they played a significant role to increase the WQI value compared with the earlier stations.

Table 10 Water Quality index (WQI) along Tigris River, wet season (2016) (Tyagi et al. 2013; Alsaqqar et al. 2015)

\begin{tabular}{lll}
\hline Stations & WQI & WQR \\
\hline Fishkhabour (1) & 63.024 & Good \\
Mosul Dam (2) & 66.202 & Good \\
Mosul (3) & 70.810 & Good \\
Shraqat (Prediction) & 73.683 & Good \\
Tikrit (4) & 75.830 & Good \\
Samarra (5) & 80.060 & Good \\
Tarmiyah (Prediction) & 86.044 & Good \\
Muthanna Bridge (6) & 89.855 & Good \\
Shuhada Bridge (7) & 93.636 & Good \\
Aziziyah (8) & 100.327 & Poor \\
Kut (9) & 105.714 & Poor \\
Ali Garbi (Prediction) & 115.278 & Poor \\
Amarah (10) & 124.744 & Poor \\
Qurnah (11) & 137.693 & Poor \\
\hline
\end{tabular}

The water quality rating in the wet and dry seasons at the Kut station (9) was within the poor category of (100-200) (Table 7), where that the values of water quality index in the wet and dry seasons were equal to 105.714 and 107.339 respectively. The values of seven parameters $\mathrm{SO}_{4}, \mathrm{HCO}_{3}$, TDS, $\mathrm{TH}, \mathrm{NO}_{3}, \mathrm{EC}$, and $\mathrm{BOD}_{5}$ which were measured at the station (9) were more than the standard allowable limits.

In both seasons (wet and dry) for the year 2016, in Tigris River, the calculated values of water quality index at Ali Garbi (prediction station), Amarah (St. 10), and Qurnah (St.11) were equal to (115.278-116.266), (124.744-125.937), and (137.693-140.060) respectively. The concentrations of eight parameters $\left(\mathrm{SO}_{4}, \mathrm{HCO}_{3}\right.$, TDS, $\mathrm{TH}, \mathrm{NO}_{3}, \mathrm{EC}, \mathrm{BOD}_{5}$, and $\left.\mathrm{Cl}\right)$ were more than the standard limits and had a high effect on the calculated values of the WQI at these stations.

The raise concentrations of $\mathrm{SO}_{4}, \mathrm{HCO}_{3}$, TDS, TH, $\mathrm{NO}_{3}$, $\mathrm{EC}, \mathrm{BOD}_{5}$, and $\mathrm{Cl}$ caused to increase the WQI values, consequently, increase deterioration of the water quality of the Tigris River gradually from upstream to downstream within Iraqi borders and deterioration increment clearly from the station (8) to the station (11).

The water quality for the stations from the station (8) in Aziziyah city until the station (11) at the Qurnah city, in addition to the prediction station at Ali Garbi city, was classified as poor based on the calculated WQI values. This is due to that most measured values of parameters at these stations (8-11) were higher than the allowable standard limits compared with the values measured in the stations (1-7) which were within the acceptable limits.

Moreover, the results showed that the WQI values were increased significantly downstream of the Tigris River and this indicated discharging pollutants into the water river system from different resources such as agricultural runoff, domestic sewers, and industrial wastes discharges. These factors and existing 
Table 11 Water quality index (WQI) along Tigris River, wet season (2016) (Tyagi et al. 2013; Alsaqqar et al. 2015)

\begin{tabular}{lll}
\hline Stations & WQI & WQR \\
\hline Fishkhabour (1) & 64.077 & Good \\
Mosul Dam (2) & 67.469 & Good \\
Mosul (3) & 71.665 & Good \\
Shraqat (Prediction) & 74.854 & Good \\
Tikrit (4) & 76.948 & Good \\
Samarra (5) & 81.459 & Good \\
Tarmiyah (Prediction) & 86.878 & Good \\
Muthanna Bridge (6) & 91.595 & Good \\
Shuhada Bridge (7) & 95.000 & Good \\
Aziziyah (8) & 101.641 & Poor \\
Kut (9) & 107.339 & Poor \\
Ali Garbi (Prediction) & 116.266 & Poor \\
Amarah (10) & 125.937 & Poor \\
Qurnah (11) & 140.100 & Poor \\
\hline
\end{tabular}

many irrigation projects starting from the capital Baghdad and passing through Aziziyah, Kut, Ali Garbi, Amarah, and Qurnah can increase the WQI values in these stations.

For the selected stations, the values of water quality index in both wet and dry seasons for the year 2016 were increased from the upstream of the Tigris River in the north of Iraq toward the south of Iraq (downstream of the river) (Fig. 14).

Generally, the originality of this paper included two parts. The first part studied the water quality using the water quality index (WQI) method for the whole length of the Tigris river within the Iraqi boundary. Then, generating the interpolation maps for the values of the WQI for irrigation purposes along the river during two seasons (wet and dry). The second part included creating the interpolation map for each parameter concentration in the GIS software along the Tigris River within the Iraqi boundary.

The WQI value for each station on the Tigris River and the interpolation map for each parameter shows a comprehensive vision about the water quality of the river, where these values will become in the future as background for researchers to

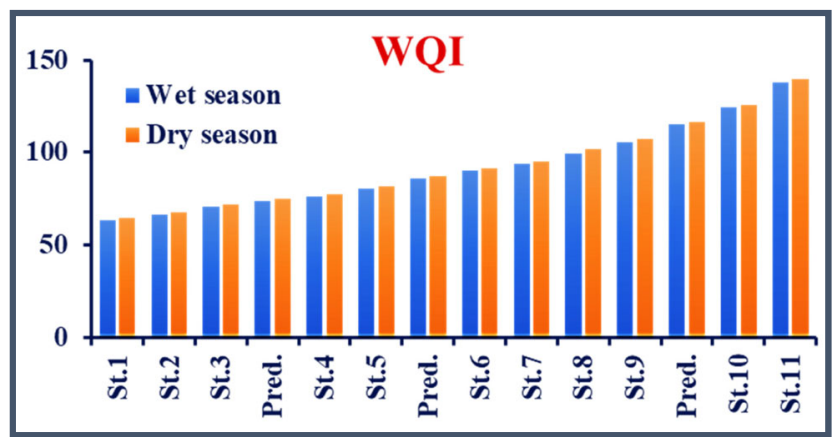

Fig. 14 Water quality index (QWI) along the Tigris River in the wet and dry seasons (2016) compare their studies results with the current study. Then, determining the contamination level in the river and find suitable methods of solutions and treatment.

The interpolation maps of the WQI distribution along the Tigris River in the wet and dry seasons based on the WQI value at each station of the river calculated in the current study can be seen in Fig. 15 a, b.

\section{Conclusions}

The Tigris River represents one of the main sources of water with the Euphrates River in Iraq. The recent water crisis in the region has prompted the necessity of assessing the quality of the river's water during the wet and dry season. Water samples from 11 stations along the Tigris River were taken in 2016 to test 12 physical and chemical parameters in the selected stations along the Tigris River. These parameters are $\mathrm{Ca}, \mathrm{Mg}, \mathrm{Na}$, $\mathrm{K}, \mathrm{Cl}, \mathrm{SO}_{4}, \mathrm{HCO}_{3}, \mathrm{TH}, \mathrm{TDS}, \mathrm{BOD}_{5}, \mathrm{NO}_{3}$, and $\mathrm{EC}$.

In this study, the maps of the selected parameters in both seasons (wet and dry) were produced using the interpolation method (IDW) between 11 stations located along the river. The IDW method was implemented in ArcGIS 10.5. The prediction maps were checked using the regression prediction which was applied to the other three stations in the Tigris River between observed values and predicted values (from the prediction maps). The results showed the determination coefficient $\left(R^{2}\right)$ for these three values were acceptable. The present study used the IDW method of the spatial analyst extension in the ArcGIS 10.5 for mapping the water quality parameters within the catchment area. This will assist in identifying the sampling locations or areas along the river with high impairment level which will in turn aid in the enforcement of standards and pollution control activities.

The measured values of all tested parameters in both seasons were increased from the station (1) in Fishkhabour (Dohuk province) to the station (11) in Qurnah (Al-Basra province) except $\mathrm{HCO}_{3}$ that was decreased along the Tigris River.

The results showed that the measured concentration values of $\mathrm{Ca}, \mathrm{Mg}, \mathrm{Na}, \mathrm{Cl}, \mathrm{SO}_{4}, \mathrm{TH}, \mathrm{BOD}$, and $\mathrm{NO}_{3}$ in the dry season were higher than the values in the wet season at all selected stations along the Tigris River, while the concentration values of TDS, EC, $\mathrm{K}$, and $\mathrm{HCO}_{3}$ in the wet season were higher than the resulted values in the dry season.

The weighted arithmetic method was applied to compute the water quality index (WQI) for each selected station along the whole length of the Tigris River within the Iraqi borders during the wet and dry seasons in 2016 using a series of equations mentioned before. The results showed that the water quality index was increased gradually progressively for the selected stations along the Tigris River from the upstream of the river (Fishkhabour) toward the downstream (Qurnah). 
Fig. 15 Distribution maps of the WQI values along Tigris River in 2016 using the interpolation method (IDW) during a wet season and $\mathbf{b}$ dry season
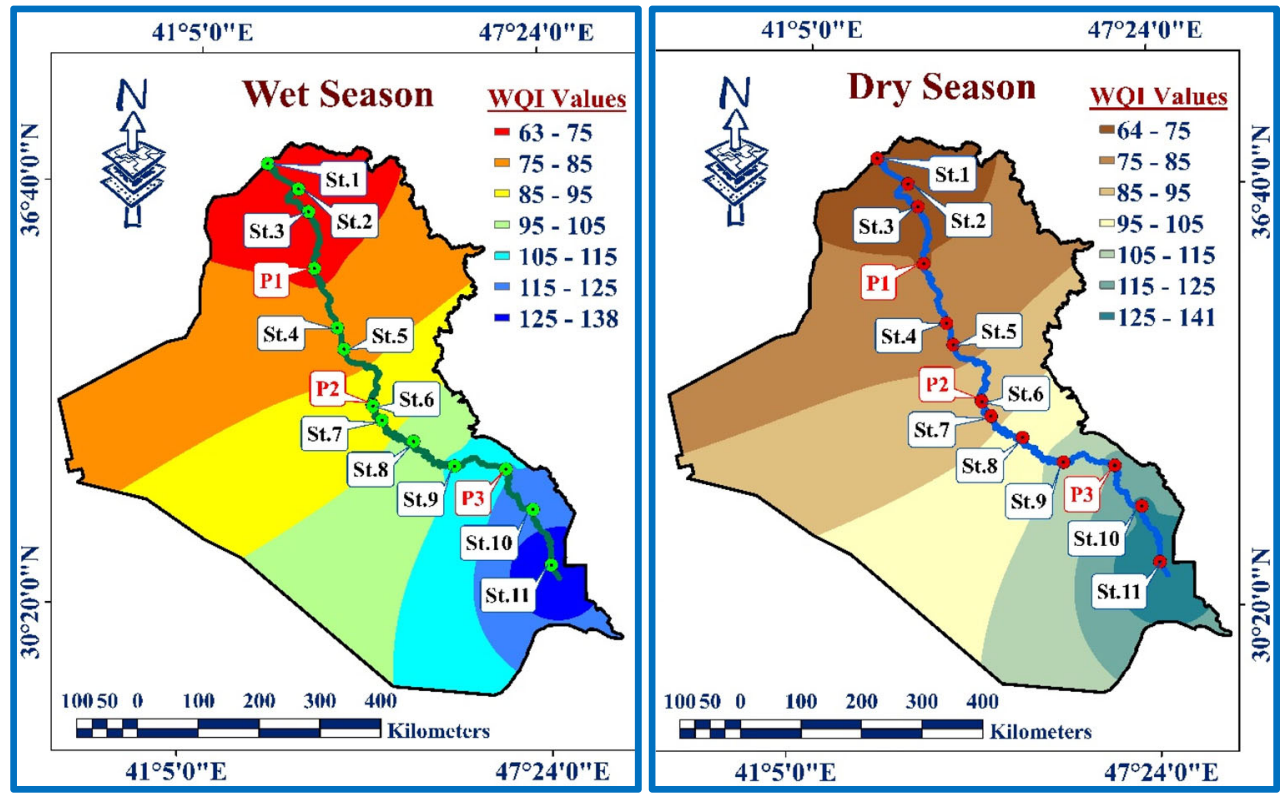

The WQI from the station (1) until the station (7) in addition to the two prediction stations (Shraqat and Tarmiyah) were calculated. The WQI values in the wet and dry seasons (respectively) were 63.024 and 64.077 (Fishkhabour (1)), 66.202 and 67.469 (Mosul Dam (2)), 70.810 and 71.665 (Mosul (3)), 73.683and 74.854 (Shraqat (Prediction), 75.830 and 76.948 (Tikrit (4)), 80.060 and 81.459 (Samarra (5)), 86.044 and 86.878 (Tarmiyah (Prediction)), 89.855 and 91.595 (Muthanna Bridge (6)), and 93.636 and 95.000 (Shuhada Bridge (7)). These stations were given the rating of good water quality in both seasons within the category of (0-100).

In the wet and dry seasons (respectively), the WQI values were 100.327 and 101.641 (Aziziyah (8)), 105.714 and 107.339 (Kut (9)), 115.278 and 116.266 (Ali Garbi (Prediction)), 124.744 and 125.937 (Amarah (10)), and 137.693 and 140.100 (Qurnah (11)). The clear degradation was increased in both seasons starting from the station (8) at Aziziyah toward station (11) at Qurnah (Basrah province) in the south of Iraq besides the prediction station at Ali Garbi, where the WQI values were higher than 100 and classified as a poor water quality within the category of (100-200). The poor water quality at these stations (811) may be related to several pollutants originating in human activities and natural phenomena factors occurring along the pathway of the river. Moreover, the computed WQI values indicated that the water quality of the river at these stations is invalid to use before treating the parameter concentrations (especially) which had values more than allowable limits.

The data of this study about Tigris River was collected and analyzed by the National Center of Water Resources Management-Ministry of Higher Education and Scientific Research (NCWRM) and Consulting Engineering Bureau (CEB), College of Engineering University of Baghdad, Iraq.

Future work will evaluate the water quality index along the Tigris river by measuring more samples including the turbidity besides the measured samples in the current study.

Acknowledgments Special thanks to the National Center of Water Resources Management-Ministry of Higher Education and Scientific Research (NCWRM) and Consulting Engineering Bureau (CEB), College of Engineering University of Baghdad, Iraq to support this research by providing the authors by all data about Tigris River.

Author contributions All authors contributed to the study conception and design. Material preparation, data collection, and analysis were performed by Ali Chabuk, Qais Al-Madhlom, Ali Al-Maliki, Nadhir AlAnsari, and Hussain Musa Hussain. The first draft of the manuscript was written by Ali Chabuk, Qais Al-Madhlom, Ali Al-Maliki, Nadhir Al-Ansari, and Hussain Musa Hussain. All authors commented on previous versions of the manuscript. All authors read and approved the final manuscript.

Funding Open access funding provided by Lulea University of Technology. This research was funded by Lulea University of Technology-Sweden and University of Babylon- Iraqi Ministry of Higher Education and Scientific Research.

Open Access This article is licensed under a Creative Commons Attribution 4.0 International License, which permits use, sharing, adaptation, distribution and reproduction in any medium or format, as long as you give appropriate credit to the original author(s) and the source, provide a link to the Creative Commons licence, and indicate if changes were made. The images or other third party material in this article are included in the article's Creative Commons licence, unless indicated otherwise in a credit line to the material. If material is not included in the article's Creative Commons licence and your intended use is not permitted by statutory regulation or exceeds the permitted use, you will need to obtain permission directly from the copyright holder. To view a copy of this licence, visit http://creativecommons.org/licenses/by/4.0/. 


\section{References}

Abahussain AA, Abdu AS, Al-Zubari WK, El-Deen NA, Abdul-Raheem M (2002) Desertification in the Arab region: analysis of current status and trends. J Arid Environ 51:521-545

Abbas JK (2013) Assessment of water quality in Tigris River-Iraq by using GIS mapping. Nat Res Forum 4:441-448. https://doi.org/10. 4236/nr.2013.46054

AccuWeather Iraq weather (2019). https://www.accuweather.com/en/iq/ sulaymaniyah/206978/august-weather/206978? year=2018. Accessed 31 October 2019

Adamo N, Al-Ansari N, Sissakian VK, Knutsson S, Laue J (2018) Climate change: consequences on Iraq's environment. J Earth Sci Geotechn Eng 8:43-58

Al-Ansari N (2013) Management of water resources in Iraq: perspectives and prognoses. Engineering 5:667-684

Al-Ansari NA (2016) Hydropolitics of the Tigris and Euphrates Basins, Engineering, V.8, 3:140-172.

Al-Ansari N, AlJawad S, Adamo N, Sissakian VK, Laue J, Knutsson S (2018a) Water quality within the Tigris and Euphrates catchments. J Earth Sci Geotechn Eng 8:95-121

Al-Ansari N, Adamo N, Sissakian V, Knutsson S, Laue J (2018b) Water resources of the Euphrates River catchment. J Earth Sci Geotechn Eng 8:1-20

Al-Ansari N, AlJawad S, Adamo N, Sissakian VK, Laue J, Knutsson S (2018c) Water quality within the Tigris and Euphrates catchments. J Earth Sci Geotechn Eng 8:95-121

Al-Ansari N, (2019a) Hydro Geopolitics of the Tigris and Euphrates, In Recent Researches in Earth and Environmental Sciences Part of the Springer Proceedings in Earth and Environmental Sciencesbook series (SPEES), Mustafa Y., Sadkhan S., Zebari S. and , Jacksi K. (Editors), 35-70.

Al-Ansari N (2019b) Variation of Water Quality of the Tigris and Euphrates Rivers, Anbar University conference on Upper Euphrates Basin Development, 18-20 March, 2019, Haditha, Iraq.

Ali SK (2018) Assessment of the Tigris River water quality in selected Iraqi governments. Int J Sci Res 7:500-504

Al-Jiburi HK, Al-Basrawi NH (2015) Hydrogeological map of Iraq, scale 1: 1000 000, 2013. Iraqi Bull Geol Min 11:17-26

Al-Madhlom Q, Nordell B, Chabuk A, Al-Ansari N, Lindblom J, Laue J, Hussain HM (2019) Potential use of UTES in Babylon Governorate, Iraq. Groundw Sustain Dev 10:1-18

Alsaqqar SA, Hashim A, Ali MA (2015) Water quality index assessment using GIS case study: Tigris River in Baghdad City. Int J Curr Eng Technol 7:2515-2520

Al-Shemari HM, Abdulhussain IA (2013) Study the effect of Baghdad city on the Tigris River water pollution. Basrah J Eng Sci 13:140-156

Alwan IA, Karim HH, Aziz NA (2019) Agro-climatic zones (ACZ) using climate satellite data in Iraq Republic. IOP Conference Series: Materials Science and Engineering 518 (022034), IOP Publishing ltd. 518; 1-12. doi:https://doi.org/10.1088/1757-899X/518/2/ 022034

Al-Zamili HS, Al-Lami AM (2018) Assessment of spatial distributions of some climate indices in Iraq. J Appl Adv Res 3:96-104

Amin MT, Mahmoud SH, Alazba AA (2016) Observations, projections and impacts of climate change on water resources in Arabian peninsula: current and future scenarios. Environ Earth Sci 75:1-17. https://doi.org/10.1007/s12665-016-5684-4

Bayazit M, Avci I (1997) Water resources of Turkey: potential, planning, development and management. Water Resour Dev 13:443-452

Beaumont P, Blake G, Wagstaff JM (2016) The Middle East: a geographical study. $2^{\text {nd }}$ edition, Imprint Routledge, publishing by Taylor and Francis Group, London
Bilgen A (2018) The southeastern Anatolia project (GAP) revisited: the evolution of GAP over forty years. New Perspect Turk 58:125-154. https://doi.org/10.1017/npt.2018.8

Bishay FK (2003) Towards sustainable agricultural development in Iraq: the transition from relief, rehabilitation and reconstruction to development. Published by FAO, Rome, Italy. http://www.fao.org/3/ Y9870E/y9870e05.htm\#bm05.2.5. Accessed 31 October 2019

Bishop TFA, McBratney AB, Whelan BM (2001) Measuring the quality of digital soil maps using information criteria. Geoderma 103:95111. https://doi.org/10.1016/S0016-7061(01)00071-4

Bouaziz M, Leidig M, Gloaguen R (2011) Optimal parameter selection for qualitative regional Erosion risk monitoring: a remote sensing study of SE Ethiopia. Geosci Front 2:237-245. https://doi.org/10. 1016/j.gsf.2011.03.004

Carré F, Girard MC (2002) Quantitative mapping of soil types based on regression Kriging of taxonomic distances with landform and land cover attributes. Geoderma 110:241-263. https://doi.org/10.1016/ S0016-7061(02)00233-1

Central Intelligence Agency (2019) The world Factbook, Middle East: Iraq. Main Content, Home Library Publications. https://www.cia. gov/library/publications/the-world-factbook/geos/iz.html\# photoGalleryModal. Accessed 30 October 2019

Chang KT (2006) Introduction to geographic information system. McGraw-Hill Higher Education, Boston

Consulting Engineering Bureau (CEB) (2017) Tigris and Euphrates Sampling. College of Engineering, University of Baghdad, Iraq, annual internal report

Daggupati P, Srinivasan R, Dile YT, Verma D (2017) Reconstructing the historical water regime of the contributing basins to the Hawizeh marsh: implications of water control structures. Sci Total Environ 580:832-845. https://doi.org/10.1016/j.scitotenv.2016.12.029

De Pauw E, Saba M, Ali SH (2015) Mapping climate change in Iraq and Jordan. International Center for Agricultural Research in the dry areas 27

Dekker AG 1993. Detection of optical water parameters for eutrophic lakes by high resolution remote sensing. Ph.D Thesis. Free University, Amsterdam

Ewaid SH, Abed SA, Kadhum SA (2018) Predicting the Tigris River water quality within Baghdad, Iraq by using water quality index and regression analysis. Environmental Technology \& Innovation 11:390-398.

FAO (2008) AQUASTAT Country Profile - Iraq. Food and Agriculture Organization of the United Nations (FAO), Rome

FAO (2009) AQUASTAT transboundary river basins-Euphrates - Tigris River Basin. Food and Agriculture Organization of the United Nations (FAO), Rome

FAO (2018) Iraq: restoration of agriculture and water systems subprogramme 2018-2020. Rome. Food and Agriculture Organization of the United Nations (FAO), Rome, Italy. License: CC BY-NC-SA 3.0 IGO, pp.110

FAO (2019a) Modelling of global irrigation water use. Food and Agriculture Organization of the United Nations (FAO), Rome, Italy. http://www.fao.org/aquastat/en/data-analysis/irrig-water-use/. Accessed 5 November 2019

FAO (2019b) Agriculture. Food and Agriculture Organization of the United Nations (FAO), Rome, Italy. www.fao.org/ag/agn/ nutrition/Indicatorsfiles/Agriculture.pdf. Accessed 5 November 2019

FAO (2019c) Countries: Iraq. Food and Agriculture Organization of the United Nations (FAO), Rome, Italy. http://www.fao.org/ countryprofiles/index/en/?iso3=IRQ. Accessed 5 November 2019

FAO (2019d) AQUASTAT: Iraq. Food and Agriculture Organization of the United Nations (FAO), Rome, Italy. https://storage.googleapis. com/fao-aquastat.appspot.com/countries regions/factsheets/ summary_statistics/en/IRQ-CF.pdf. Accessed 5 November 2019 
FAO (2019e) AQUASTAT: Iraq. Food and Agriculture Organization of the United Nations (FAO), Rome, Italy. https://storage.googleapis. com/fao-aquastat.appspot.com/countries regions/factsheets/ irrigation_area/en/IRQ-IRR.pdf. Accessed 5 November 2019

FAO (2019f) AQUASTAT: Iraq. Food and Agriculture Organization of the United Nations (FAO), Rome, Italy. http://www.fao.org/nr/ water/aquastat/data/query/results.html. Accessed 4 November 2019

FAO (2019g) AQUASTAT: Iraq, Water Resources and Summary Statistics. Food and Agriculture Organization of the United Nations (FAO), Rome, Italy. http://www.fao.org/nr/water/aquastat/ data/query/results.html. Accessed 6 November 2019

Fetter CW (2018) Applied hydrogeology. $4^{\text {th }}$ edition, Waveland press, USA, ISBN 1: 1-4786-3709-9

Flaieh HM, Abdul-Ahad MY, Mohammed-Ridha MJ (2014) Assessing Tigris River Water Quality in Baghdad city Using Water Quality Index and Multivariate Statistical Analysis. International Journal of Engineering Sciences \& Research Technology 3: 687-699.

Frenken K (2009) Irrigation in the Middle East region in figures, AQUASTAT Survey-2008. FAO water reports. Published by food and agriculture Organization of the United Nations (FAO), Rome, Italy, 34. ISSN 1020-120

Goff JA, Nordfjord S (2004) Interpolation of fluvial morphology using channel oriented coordinate transformation: a case study from the New Jersey shelf. Math Geol 36:643-658

Hengl T (2009) A practical guide to geostatistical mapping. $2^{\text {nd }}$ edition. EUR 22904 EN Scientific and Technical Research series report. Published by Office for Official Publications of the European Communities, Luxembourg (ISBN: 978-92-79-06904-8), pp15

Hussain MR, Abed BS (2019) Simulation and assessment of groundwater for domestic and irrigation uses. Civil Eng J 5:1877-1892

International Energy Agency (2019) Iraq's energy sector, a roadmap to a brighter future. Published by International Energy Agency. Pp 59. https://www.connaissancedesenergies.org/sites/default/files/pdfactualites/Iraq_Energy_Outlook.pdf. Accessed 4 November 2019

Issa IE, Al-Ansari N, Sherwany G, Knutsson S (2014) Expected future of water resources within Tigris-Euphrates Rivers Basin, Iraq. J Water Resour Protect 6:421-432. https://doi.org/10.4236/jwarp.2014. 65042

Jassim S, Goff J (2006) Geology of Iraq, 1st Edition. Dolin, Prague and Moravian Museum, Brno, Czech Republic, distributed by Geological Society of London

Khudair BH, Jasim MM, Alsaqqar AS (2018) Artificial neural network model for the prediction of groundwater quality. Civil Eng J 4: 2959-2970

Kibaroglu A (2019) State of the-art review of Transboundary water governance in the Euphrates -Tigris River basin. Int J Water Resour Dev 35:4-29. https://doi.org/10.1080/07900627.2017.14

Library of Congress - Federal Research Division (2006) Country Profile: Iraq. https://www.loc.gov/rr/frd/cs/profiles/Iraq.pdf. Accessed 5 November 2019

Longley PA, Goodchild MF, Maguire DJ, Rhind DW (2005) Geographic information systems and science, 2nd edn. John Wiley \& Sons, England

Madhloom HM, Alansari N (2018) Geographical information system and remote sensing for water resources management case study: the Diyala River, Iraq. Int J Civil Eng Technol 9:971-984

Meng W, Zhang N, Zhang Y, Zhang BH (2009) Integrated assessment of river health based on water quality, aquatic life and physical habitat. J Environ Sci 21:1017-1027

Merwade V (2009) Effect of spatial trends on interpolation of river bathymetry. J Hydrol 371:169-181

Merwade VM, Maidment DR, Goff JA (2006) Anisotropic considerations while interpolating river channel bathymetry. J Hydrol 331: 731-741
Ministry of Industry and Technology (2019) what's Gap. Southeastern Anatolia Project, Regional Development Administration, Turkey, home. http://www.gap.gov.tr/en/what-s-gap-page-1.html. Accessed 28 October 2019

Mohammed SI, Abdulrazzaq KA (2018) Developing water quality index to assess the quality of the drinking water. Civil Eng J 4:2345-2355

Morshed MM, Islam MT, Jamil R (2016) Soil salinity detection from satellite image analysis: an integrated approach of salinity indices and field data. Environ Monit Assess 188:119. https://doi.org/10. 1007/s10661-015-5045-x

Mutlak SM, Salih BM, Tawfiq SJ (1980) Quality of Tigris River passing through Baghdad for irrigation. Water Air Soil Pollut 13:9-16

National Center of Water Resources Management (NCWRM) 2017. Water Quality Study of Main Rivers in Iraq, Ministry of Water Resources, Iraq, annual internal report

National Oceanic and Atmospheric Administration (2019) Iraq (NOAA). Iraq Climatological Data, NOAA Central Library. https://ibrary. noaa.gov/Collections/Digital-Docs/Foreign-Climate-Data/IraqClimate-Data. Accessed 30 October 2019

Numaan MM (2011) Quality assessment of Tigris River by using water quality index for irrigation purpose. Eur J Sci Res 57:15-28

Oke A, Sangodoyin A, Ogedengbe K, Omodele T (2013) Mapping of river water quality using inverse distance weighted interpolation in Ogun-Osun river basin, Nigeria. Acta Geograph Debrecina Landsc Environ 7:48-62

Panhalkar SS, Jarag AP (2015) Assessment of spatial interpolation techniques for river bathymetry generation of Panchganga River basin using Geoinformatic techniques. Asian J Geoinform 15:10-15

Rabee AM, Abdul-Kareem BM, Al-Dhamin AS (2011) Seasonal Variations of Some Ecological Parameters in Tigris River Water at Baghdad Region, Iraq. Journal of Water Resource and Protection 3: 262-267. https://doi.org/10.4236/jwarp.2011.34033

Rahi KA, Halihan T (2018) Salinity evolution of the Tigris River. Reg Environ Chang 18:2117-2127. https://doi.org/10.1007/s10113-018$1344-4$

Solomon S (2010) Water: the epic struggle for wealth, power, and civilization. Published by Harper Perennial, New York, USA ISBN 978-0-06-054831-5

Srivastava PK, Mukherjee S, Gupta M, Singh SK (2011) Characterizing monsoonal variation on water quality index of river Mahi in India using geographical information system. Water Qual Expo Health 2: 193-203. https://doi.org/10.1007/s12403-011-0038-7

The World Bank (2006) Iraq - country water resource assistance strategy: addressing major threats to People's livelihoods. Water, Environment, Social and Rural Development Department Middle East and North Africa Region. http://documents.worldbank.org/ curated/en/944501468253199270/pdf/362970IQ.pdf. Accessed 28 October 2019

Tyagi S, Sharma B, Singh P, Dobhal R (2013) Water quality assessment in terms of water quality index. Am J Water Resour 1:34-38

Voss KA, Famiglietti JS, Lo M, De Linage C, Rodell M, Swenson SC (2013) Groundwater depletion in the Middle East from GRACE with implications for Transboundary water Management in the Tigris-EuphratesWestern Iran Region. Water Resour Res 49:904-914

Watson DF, Philip GMA (1985) Refinement of inverse distance weighted interpolation. Geoprocessing 2:315-327

World Health Organization (2006) Guidelines for drinking water quality, 3rd edn. WHO, Geneva

Ying X, Zeng GM, Chen GQ, Tang L, Wang KL, Huang DY (2007) Combining AHP with GIS in synthetic evaluation of ecoenvironment quality - a case study of Hunan province, China. Ecol Model 209:97-109

Zhang L (2019) Big data, knowledge mapping for sustainable development: a water quality index case study. Emerg Sci J 3:249-254 